\title{
Preventing pressure ulcers by assessment of the microcirculation in tissue exposed to pressure
}

\author{
Sara Bergstrand \\ Division of Nursing Science \\ Department of Medical and Health Sciences \\ Linköping University, Sweden

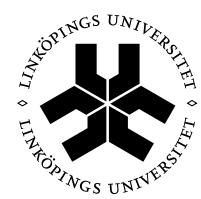 \\ Linköping University \\ FACULTY OF HEALTH SCIENCES
}

Linköping 2014 
During the course of the research underlying this thesis, Sara Bergstrand was enrolled in Forum Scientium, a multidisciplinary graduate school at Linköping University, Sweden

CSara Bergstrand, 2014

Cover picture: Katja Kircher, Katja Kircher Photography AB, Linköping, Sweden

Published articles have been reprinted with the permission of the copyright holders

Printed in Sweden by LiU-Tryck, Linköping, Sweden, 2014

ISBN 978-91-7519-317-5

ISSN 0345-0082 
To Ingegerd

for the dissertation

that was never written

All my love to Patrik, Vidar \& Henning 



\section{CONTENTS}

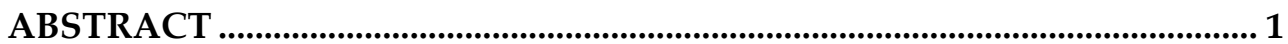

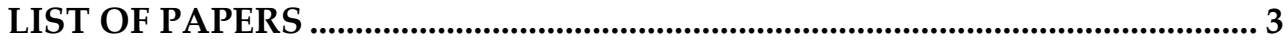

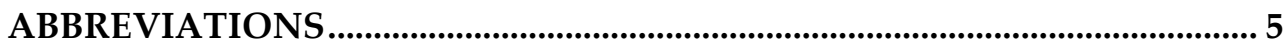

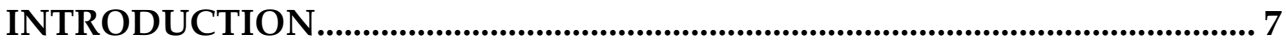

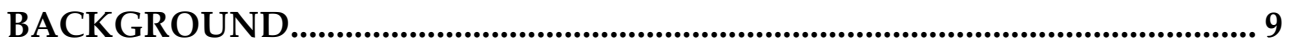

Pressure ulcer etiology ......................................................................................... 9

Prevention of pressure ulcers ............................................................................. 11

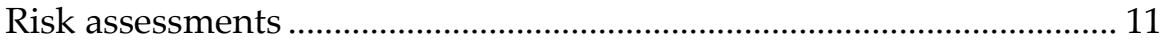

Evaluation of pressure redistribution support surfaces .......................... 12

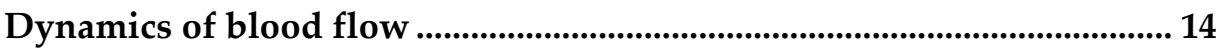

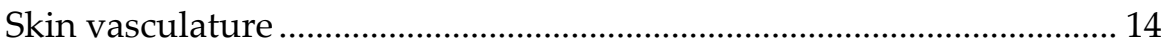

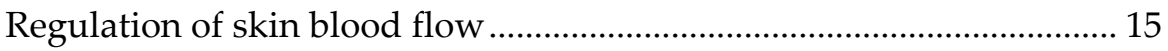

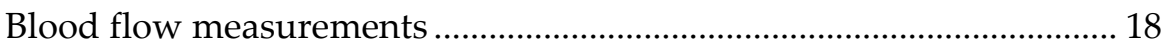

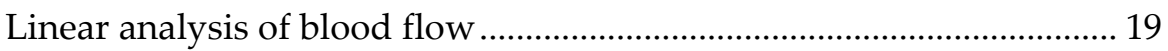

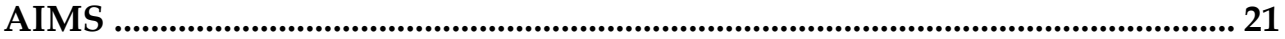

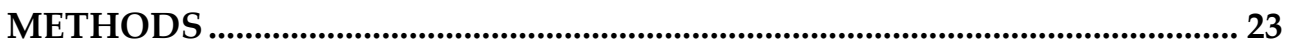

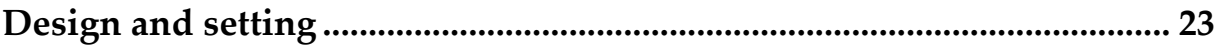

Participants........................................................................................................... 25

Procedures …............................................................................................... 26

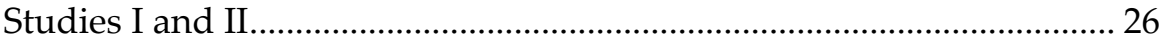

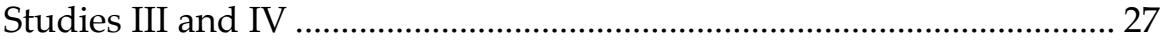

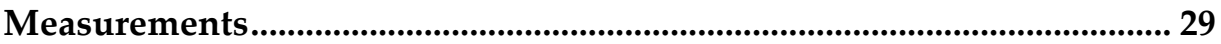

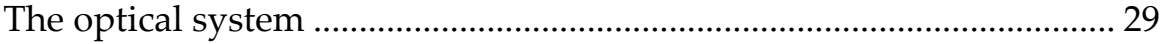

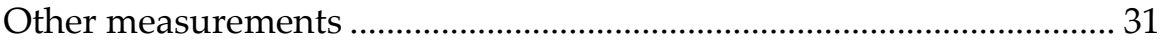

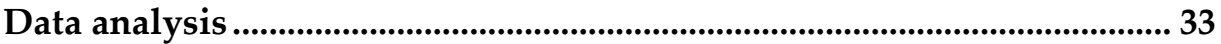

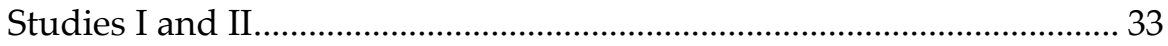




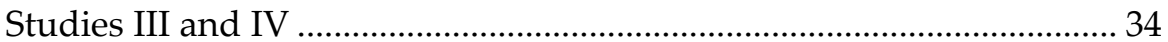

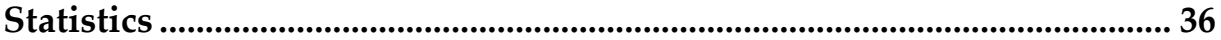

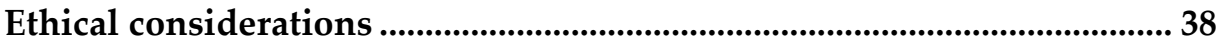

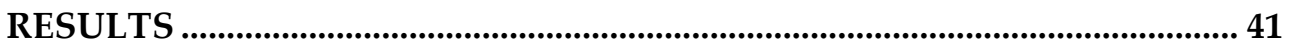

Tissue characterization ....................................................................................... 41

Variations in blood flow ...................................................................... 42

Pressure-induced vasodilation during load ............................................. 44

Blood flow during the post-load period....................................................... 45

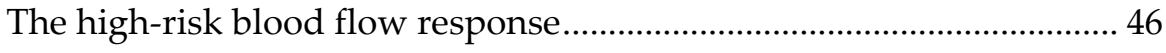

Pressure

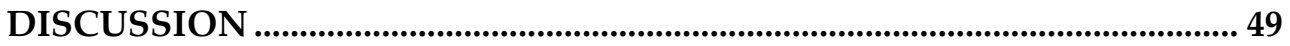

Variations in blood flow ................................................................................. 49

Perspectives on microcirculation and pressure ulcer etiology ............... 49

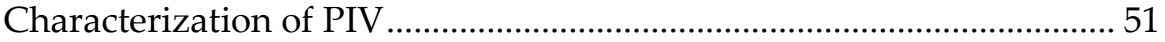

Evaluation of support surfaces.................................................................... 52

The development and evaluation of the probe................................................. 54

Measurement depths ............................................................................. 54

Considerations of the optical techniques ................................................... 55

Influences of the prototype probe ……..................................................... 56

Methodological considerations ......................................................................... 57

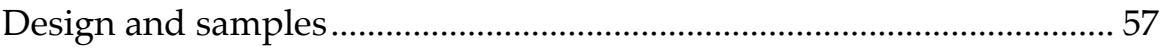

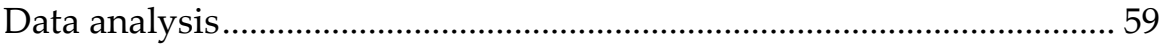

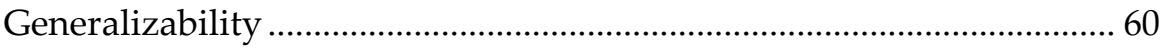

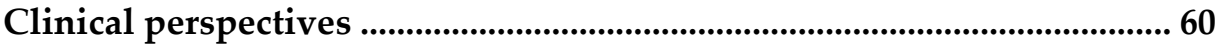

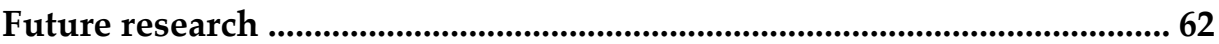

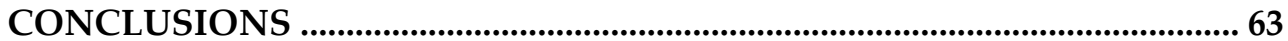

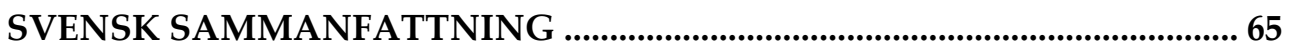

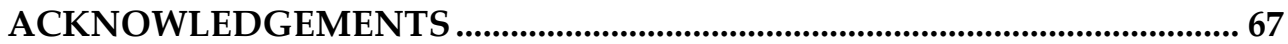

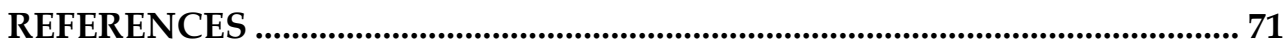




\section{ABSTRACT}

Pressure ulcers are related to illness and immobility and have a significant impact on many aspects of the afflicted individual's quality of life. They lead to great expenditures for health-care systems and society but are generally preventable. In clinical practice, the main emphasis has been on identifying persons at risk of pressure ulcer development and then implementing preventive interventions. In these efforts, structured risk assessments and the use of pressure-redistribution support surfaces are common practice. However, it is difficult to select the most effective support surface for clinical use because most products have only been poorly evaluated. The etiology of pressure ulcers is not fully understood, but knowledge of the key components and their impact on tissue damage will guide risk assessment and practice.

The overall aim of this thesis was to combine optical methods into a system with the ability to simultaneously measure blood flow changes at different tissue depths. The goal of such a system was to reveal vascular mechanisms relevant to pressure ulcer etiology under clinically relevant conditions and in relation to the evaluation of pressure-redistribution support surfaces.

This thesis consists of four quantitative, cross-sectional experimental studies measuring blood flow responses before, during, and after pressure exposure of the sacral tissue. Two optical methods - photoplethysmography and laser Doppler flowmetry - were combined in a newly developed system that has the ability to discriminate blood flows at different tissue depths. Studies I and II were descriptive and explored blood flow responses at different depths in 17 individuals. The pressure magnitude was at least $220 \mathrm{mmHg}$ (Study I) during pressure exposure, and the blood flow was related to tissue thickness and tissue compression. In Study II, the sacral tissue was loaded with 37.5 $\mathrm{mmHg}$ and $50.0 \mathrm{mmHg}$, and the variation in blood flow was measured. In Studies III and IV, 42 healthy individuals younger than 65 years, 38 healthy individuals of at least 65 years, and 35 patients of at least 65 years were included. Study III added between-subject comparisons of blood flow and pressure between individuals in the three study groups lying in supine positions on a standard hospital mattress. Study IV expanded upon this by including withinsubject comparisons while the individual was lying on four different types of mattress. The design of the blood flow measurements were longitudinal trend studies exploring the vascular phenomena of pressure-induced vasodilation (PIV) and reactive hyperemia (RH). 
The results in Study I showed that the mean sacral tissue thickness was $26 \pm 13$ $\mathrm{mm}$ and that this decreased to $10 \pm 5 \mathrm{~mm}$ during pressure exposure of at least $220 \mathrm{mmHg}$. Measurement depths of $1 \mathrm{~mm}, 2 \mathrm{~mm}$ and $10 \mathrm{~mm}$ were shown to be suitable for measurements in sacral tissue. The most common response to tissue exposure was PIV, although a decrease in blood flow (a lack of PIV) was observed in some individuals. A total of $40.0 \%-85.7 \%$ of the subjects had $\mathrm{RH}$ depending on measurement depths (Study III). In addition, approximately $24 \%-26 \%$ of the individuals in the groups in Study III appeared to be particularly vulnerable to pressure exposure and lacked both PIV and RH responses. In Study IV, 7\%-8\% of the individuals in the healthy groups and 14\% of the patients had this high-risk response on three or four mattresses. In Studies III and IV, the patients tended to have higher interface pressure during pressure exposure than the healthy groups but no differences in blood flow responses were seen. Our results showed that pressure levels that are normally considered to be harmless could have a significant effect on the microcirculation in different tissue structures. Differences in individual blood flow responses in terms of PIV and $\mathrm{RH}$ were seen in these studies, and a larger proportion of individuals lacked these responses in the deeper tissue structures compared to more superficial tissue structures. In addition, a larger proportion of individuals lacking these responses was seen with the visco-elastic foam/air mattress compared to the alternating pressure mattress and the standard hospital mattress (Study IV).

This thesis identified PIV and RH that are important vascular mechanisms for pressure ulcer development and revealed for the first time that PIV and RH are present at different depths under clinically relevant conditions. The thesis also identified a population of individuals not identified in previous experimental studies who lack both PIV and RH and seem to be particularly vulnerable to pressure exposure. Further, this thesis has added a new perspective to the microcirculation in pressure ulcer etiology in terms of blood flow regulation and endothelial function that are anchored in clinically relevant studies. Finally, the evaluation of pressure-redistribution support surfaces in terms of mean blood flow during and after tissue exposure was shown to be unfeasible, but the assessment of PIV and RH could provide a new possibility for measuring individual physiological responses that are known to be related to pressure ulcer development.

Keyword: pressure ulcer, photoplethysmography, laser Doppler flowmetry, non-invasive, tissue blood flow, reactive hyperemia, pressure-induced vasodilation, interface pressure, risk assessment 


\section{LIST OF PAPERS}

This thesis is based on the following papers, which will be referred to by their Roman numerals.

I. Existence of Tissue Blood Flow in Response to External Pressure in the Sacral Region of Elderly Individuals - Using an optical Probe Prototype. Sara Bergstrand, Toste Länne, Anna-Christina Ek, LarsGöran Lindberg, Maria Lindén and Margareta Lindgren. Microcirculation 2010; 17: 311-319.

II. Blood flow measurements at different depths using photoplethysmography and laser Doppler techniques. Sara Bergstrand, Lars-Göran Lindberg, Anna-Christina Ek, Maria Lindén and Margareta Lindgren. Skin Research and Technology 2009; 15: 139-147.

III. Pressure-induced vasodilation and reactive hyperemia at different depths in sacral tissue under clinically relevant conditions. Sara Bergstrand, Ulrika Källman, Anna-Christina Ek, Lars-Göran Lindberg, Maria Engström, Folke Sjöberg and Margareta Lindgren. Microcirculation 2014 doi: 10.1111/micc.12160. [Epub ahead of print].

IV. Exploring pressure-induced microcirculatory responses in sacral tissue in healthy individuals and inpatients on different pressureredistribution mattresses. Sara Bergstrand, Ulrika Källman, AnnaChristina Ek, Maria Engström and Margareta Lindgren (submitted). 



\section{ABBREVIATIONS}

\begin{tabular}{|c|c|}
\hline AC signal & Alternating Current Signal \\
\hline Asic3 & Acid-sensing ion channel 3 \\
\hline BFload & Blood flow during load \\
\hline $\mathrm{BF}_{\max }$ & Maximal blood flow after load \\
\hline $\mathrm{BF}_{\text {overall }}$ & The overall blood flow after load \\
\hline BMI & Body Mass Index \\
\hline DC signal & Direct Current Signal \\
\hline $\mathrm{DP}$ & Diastolic Pressure \\
\hline DTI & Deep Tissue Injury \\
\hline EDHF & Endothelial-Derived Hyperpolarizing Factors \\
\hline EPUAP & European Pressure Ulcer Advisory Panel \\
\hline HRP & High-Resilience Polyurethane \\
\hline IR & Infrared \\
\hline LED & Light-Emitting Diode \\
\hline LDF & Laser Doppler Flowmetry \\
\hline MAP & Mean arterial pressure \\
\hline $\mathrm{mmHg}$ & Millimeters of Mercury \\
\hline $\mathrm{NO}$ & Nitric Oxide \\
\hline NPUAP & National Pressure Ulcer Advisory Panel \\
\hline OLD & study group $\geq 65$ years \\
\hline PG & Prostaglandins \\
\hline PIV & Pressure-Induced Vasodilation \\
\hline PPG & Photoplethysmography \\
\hline RAPS & Risk Assessment Pressure Ulcer Scale \\
\hline $\mathrm{RBC}$ & Red Blood Cells \\
\hline $\mathrm{RH}$ & Reactive Hyperemia \\
\hline S3I & the Support Surface Standards Initiative \\
\hline SP & Systolic Pressure \\
\hline Timemax & the point in time where $B F_{\max }$ occurred \\
\hline TTload & Sacral tissue thickness during load \\
\hline TTunload & Sacral tissue thickness \\
\hline V-E & Visco-elastic \\
\hline YOUNG & study group $<65$ years \\
\hline
\end{tabular}





\section{INTRODUCTION}

Pressure ulcers are complications related to the care and treatment of individuals who have difficulty moving or changing positions. Pressure ulcers can affect the person's health-related quality of life (Thein et al., 2010) and can have a significant impact on many other aspects of their life (Gorecki et al., 2010). Symptoms such as pain, discomfort, exudate, and odor can occur, and these can further restrict mobility and daily activities as well as lead to disturbed sleep and a general malaise. The patient's psychological well-being can be affected by feelings of anxiety, worry, and dependence as well as by reduced feelings of self-efficacy and self-confidence. Further, pressure ulcers can lead to social isolation and the inability to participate in social activities (Gorecki et al., 2010).

Pressure ulcers are a frequent medical issue. A European study in hospitals in five countries found a prevalence of $18.1 \%$ (Vanderwee et al., 2007). In the US, an overall prevalence of $6.3 \%-6.7 \%$ was reported in 207 hospitals in 2009 (Gunningberg et al., 2012). In Sweden, a national pressure ulcer prevalence survey is performed annually among all 21 county councils and 290 municipalities in the country. In 2011, this survey included 35,058 persons and reported an overall prevalence of pressure ulcers of $16.6 \%$ in hospitals and $14.5 \%$ in nursing home residents. The highest levels $(21.9 \%)$ were seen in shortterm care for the elderly (Gunningberg et al., 2013).

Pressure ulcers are costly to treat. No data for the economic impact of pressure ulcers in Sweden are available, but there are data from other European countries that can be expected to be transferrable to Swedish conditions. In the Netherlands, the cost of illness from pressure ulcers has been conservatively estimated to account for approximately $1 \%$ of the country's total health-care budget (Severens et al., 2002). The cost of treating a pressure ulcer in the UK varied from 1,064 GBP for a grade 1 ulcer to 10,551 GBP for a grade 4 ulcer, with most of the cost due to nursing time (Bennett et al., 2004). The total cost was approximately $4 \%$ of the total National Health Service budget. In a spinal cord injury population, the average monthly cost per individual with a pressure ulcer was reported to be $\$ 4,745$ of which the hospital costs represented $62 \%$ (Chan et al., 2013).

In recent decades, significant attention has been paid to the prevention of pressure ulcers and to the importance of early detection of potential tissue damage. Structured risk assessments and individual prevention regimens for 
at-risk persons are important components in simplification and standardization of pressure ulcer interventions and documentation, that are important parts of reducing pressure ulcer rates in health-care systems (Sullivan and Schoelles, 2013). Structured risk assessments refer to the systematic collection of information that links a person to a level of risk and usually involve risk assessment scales (Coleman et al., 2013). In the preventive efforts, pressureredistribution mattresses and seat cushions are widely used and are recommended in health-care settings as aids for pressure ulcer prevention (Bedo, 2013). Evaluation of these support surfaces focuses on a general evaluation such as reporting the incidence of new pressure ulcers (McInnes et al., 2012) or on quantification of the interface pressure (Gil-Agudo et al., 2009, Miller et al., 2013, Moysidis et al., 2011). However, the difficulties of interpreting the results of interface pressure analysis are well known (Oomens et al., 2010, Reenalda et al., 2009), and this makes it difficult to select the most effective and cost-effective products for clinical use.

Pressure ulcers are caused by prolonged pressure exposure of the soft tissues, but the detailed mechanisms of pressure ulcer development are not fully understood. Theories concerning the connection between pressure exposure and tissue damage often include ischemia (Shilo and Gefen, 2012), and localized ischemia is commonly accepted as a significant contributor to pressure ulcer etiology (Jiang et al., 2011, Kosiak, 1959). Aligned with this theory, assessment of the microcirculation has been suggested to be a good way to explore mechanisms of pressure ulcer prevention (Liao et al., 2013).

Microcirculation can be assessed by quantifying changes in response to stimuli, including pressure, temperature, and vasoactive agents (Liao et al., 2013, Roustit and Cracowski, 2013). Studies of the microcirculation can be performed using non-invasive methodologies, and optical methods have been used to evaluate both vascular pathophysiology and vascular function. Studies of blood flow regulation are performed in many clinical applications (Allen, 2007, Liao et al., 2013).

This thesis will explore the novel possibilities of combining optical methods into a system with the ability to measure blood flow changes at different tissue depths as a way to reveal vascular mechanisms that are relevant to pressure ulcer etiology under clinically relevant conditions. This thesis also describes attempts to use these measurements to evaluate pressure-redistribution support surfaces. 


\section{BACKGROUND}

\section{Pressure ulcer etiology}

A widely used definition for a pressure ulcer is "localized injury to the skin and/or underlying tissue, usually over a bony prominence, as a result of pressure or pressure in combination with shear"(NPUAP/EPUAP, 2009).

The literature describes two different pathways for pressure ulcer development based on both pathological and histological data. The first pathway describes a top-to-bottom ulcer formation that starts on the skin surface (Bridel, 1993, Witkowski and Parish, 1982). If the pressure is not relieved, the ulcerations progress deeper through the epidermis and upper dermis and down into the deep tissue and muscle. The initial structural changes are found in the vessels of the papillary dermis, and these are followed by necrosis in the skin structures at increasing depths (Witkowski and Parish, 1982). It has been suggested that the initial tissue damage is due to the occlusion of the blood vessels by external pressure, endothelial damage to arterioles, and reduced microcirculation due to the presence of disruptive and shearing forces (Bridel, 1993). The second pathway describes initial pathologic changes that occur in the muscle due to its higher metabolism compared to cutaneous tissue that leads to a higher sensitivity to ischemia (Daniel et al., 1981, Salcido et al., 1994). Bouten et al. suggested that superficial tissue damage is caused by shear stress in the skin layers and that the deeper tissue damage is due to sustained compression of the tissues (Bouten et al., 2003). On the basis of the second pathway, the theory of deep tissue injury (DTI) has been developed (Berlowitz and Brienza, 2007, Kottner et al., 2010). "DTI is a purple or maroon localized area of discolored intact skin that results from damage to the underlying soft tissue due to continuous pressure and/or shear" (Black et al., 2007). The cause of this phenomenon is considered to be a combination of deformation of the cells that leads to rapid tissue damage and ischemia that has long-term impacts on the tissues (Stekelenburg et al., 2008).

The detailed mechanisms behind these two pathways and their relative contribution to pressure ulcer development have been widely discussed. Four main factors are believed to be involved, including ischemia (Shilo and Gefen, 2012), cell deformation (Shoham and Gefen, 2012), impaired lymphatic drainage (Kasuya et al., 2014), and reperfusion injury (Jiang et al., 2011). The ischemia 
theory was first developed by Kosiak (1961) and then expanded upon by Witkowski and Parish (Kosiak, 1961, Witkowski and Parish, 1982). The theory is based on the view that the circulation transports oxygen and metabolites to and from the cells and that pressure disturbs the transport function leading to local tissue ischemia that is made worse by toxic metabolites that accumulate in the tissue (Dinsdale, 1974, Kosiak, 1961). Studies based on this theory include measurements of skin blood flow in both animals and humans (Bennett et al., 1981, Mayrovitz and Smith, 1998, Sae-Sia et al., 2007, Sanada et al., 1997, Schubert and Fagrell, 1991).

The theory of deformation has gained ground along with the development of novel techniques for measuring changes in whole tissue structures in terms of tissue stress and relative deformation of the tissue exposed to pressure. These studies are based on animal and engineered muscle tissue together with finiteelement modeling (Ceelen et al., 2008, Linder-Ganz and Gefen, 2004, LinderGanz et al., 2007). These bioengineering studies suggest that deformation is mainly involved in the damage process over short periods of pressure exposure and that ischemia and reperfusion increase over time and become the dominant factors during prolonged pressure exposure (Oomens et al., 2010). The deformation theory is also closely related to the theory of DTI (Gefen, 2007, Stekelenburg et al., 2008).

Lymphatic circulation has been suggested to play a role in pressure ulcer development because an occlusion of the lymph vessels can lead to an increase in the interstitial fluid and an accumulation of waste products (Kasuya et al., 2014, Miller and Seale, 1981, Reddy and Cochran, 1981).

The relationship between pressure ulcer development and ischemiareperfusion injury has been described as an inflammatory reaction in the tissue combined with oxidative tissue stress due to hyperemia in the ischemic tissues, leading to cell apoptosis and necrosis (Jiang et al., 2011, Peirce et al., 2000, Xiao et al., 2014).

Several studies have found connections between the different factors, for example, between lymphatic dysfunction and ischemia-reperfusion injury (Kasuya et al., 2014), between deformation and inflammatory reactions and ischemia (Stojadinovic et al., 2013), between shear and blood flow (Manorama et al., 2013), between deformation and ischemia (Stekelenburg et al., 2007), and between deformation and occlusion (Shilo and Gefen, 2012).

An additional approach is aligned with the ischemia theory, but this sees the microcirculation as more than just a transport system and takes into account the endothelial function of regulating the blood flow as a means to protect the tissue that is exposed to pressure. The ability of the endothelium to respond to 
ischemic stress suggests that measuring blood-flow dynamics might allow for the identification of people who are at risk for developing pressure ulcers (Fromy et al., 2012, Liao et al., 2013, Schubert and Fagrell, 1991).

Taken together, pressure ulcer etiology seems to involve complex interactions between several physiological mechanisms.

\section{Prevention of pressure ulcers}

\section{Risk assessments}

Risk assessment is used in many areas in health-care systems and is based on a structured collection of information that relates an individual to a certain level of risk (Sprigle et al., 2013). To assess the risk of pressure ulcer, special pressure ulcer risk assessment scales have been developed over the last few decades. The variables used in these scales have been identified in studies of pressure ulcer risk using observational cohort research designs that rely on the natural occurrence of pressure ulcers (Coleman et al., 2013). These scales are based on generalized assessments of the factors known to contribute to ulceration, and the variables typically involve common clinical routines such as clinician observations, patient reports, and blood samples. The purpose is to guide the clinician in preventive interventions.

A recent review identified 54 studies of risk factors of pressure ulcer development that included a total of 34,449 persons (Coleman et al., 2013). The authors found no single factor that could explain pressure ulcer risk and concluded that such an increased risk of ulceration is the result of complex interactions between many factors. However, they identified the following three domains that included the most frequent emerging risk factors in the different studies: mobility/activity, skin/pressure ulcer status, and perfusion. Mobility/activity refers to descriptors of immobility by being bed-ridden or chair-bound, reduced ability to engage in general activities in daily life, friction, shear, and interface pressure. Skin/pressure ulcer status refers to variables describing existing or previous Stage 1 pressure ulcers and general skin status. Perfusion refers to the presence of diabetes, vascular disease, or edema, the use of tobacco, and assessments of circulation and blood pressure. They stated that skin moisture, age, hematologic measures, nutrition, and general health are important, but the evidence for these in the etiology of pressure ulcers is weaker than for the three factors described above. They also showed that there was no 
evidence that race or gender are risk factors for pressure ulcer development. Body temperature and immunity might be of importance for pressure ulcer risk, but these need further investigation (Coleman et al., 2014).

Due to the complexity of the factors contributing to pressure ulcer development, it is difficult for the clinician to use the results from the risk assessment scale to develop individualized prevention strategies, and a total risk score does not assist the clinician in such efforts (Tescher et al., 2012). Instead, Tescher et al. have proposed using the total risk score as a risk alert assessment and then using other measures such as the subscale scores to develop an individualized prevention plan for the specific patient. Others have focused on the need for objective and quantifiable technology to measure the physiological and biomechanical factors that are related to pressure ulcer risk (Judy et al., 2011, Sprigle et al., 2013).

\section{Evaluation of pressure redistribution support surfaces}

In the efforts to prevent and treat pressure ulcers, the use of pressureredistribution support surfaces - such as mattresses, overlays, and seat cushions - has been widely recommended (Bedo, 2013). The definition of a pressureredistribution support surface used in this thesis is based on The Support Surface Standards Initiative (S3I), Terms and Definitions: “A specialized devise for pressure redistribution designed for management of tissue loads, microclimate and/or other therapeutic functions" (NPUAP/S3I, 2007). These support surfaces have been available since the 1950s and were originally designed for treatment of napalm burns during the Vietnam War and for use in the NASA space program (Clancy, 2013). These commercially available products have evolved over the years and their use has increased dramatically, but the basis of the technology has been the same for more than 40 years and includes polyurethane foam, alternating pressure, air-fluidized low air loss, or continuous low pressure. The main purpose of these products, except those based on alternating pressure, is to make as large a contact area as possible with the body - referred to as immersion - and to adjust to anatomical prominences such as the heels - referred to as envelopment (TVS, 2010). The principle of alternating pressure is to change the location on the body where the tissue is exposed to pressure, and this is performed by air-filled cells at the support surface that are alternately inflated and deflated. 
The users and prescribers of these products have a wide variety available to them on the market, and each has different properties. The manufacturers' promotional literature and manuals are often biased and might be of little help in the selection of a specific product for the individual in need (Rithalia, 2005). Efficacy of the product type and differences between products has always been difficult to demonstrate and only a few randomized clinical trials have been carried out (Clancy, 2013). The evaluation of different products has focused on a general evaluation of the incidence of new pressure ulcers (McInnes et al., 2012). This Cochrane review stated that higher-specification foam mattresses were better than standard hospital mattresses, but the evidence for the usefulness of mattresses with constant low pressure or alternating pressure was unclear.

Traditionally, the evaluation of these support surfaces from the manufacturers' point of view has been focused on pressure measures such as interface pressure (TVS, 2010). However, several researchers have highlighted the limitations of only performing interface pressure measurements to evaluate pressure-relieving support surfaces. Studies on internal deformation and stress in the whole tissue volume under the pressure-exposed body surface have concluded that deeper tissue structures can be highly affected by the pressure exposure despite a relatively low interface pressure at the skin surface (Gefen and Levine, 2007, Linder-Ganz et al., 2007, Oomens et al., 2010, Oomens et al., 2003). This suggests that interface pressure measurements alone are inappropriate for evaluation of these products. A review of the relation between interface pressure and the incidence or healing of pressure ulcers found that no quantification of the predictive or prognostic value of interface pressure can be given (Reenalda et al., 2009). Work has been undertaken to develop standardized pressure measurement protocols to be able to compare the technical performance of specific products by evaluating specific physiological responses (TVS, 2010). Based on its role in pressure ulcer etiology, suggested parameters that are relevant to evaluate in relation to interface pressure include blood flow distribution, temperature, and humidity (Jonsson et al., 2005). Some attempts to perform blood flow measurements as a way to evaluate support surfaces have been performed, but these have proven difficult due to the large variations in blood flow responses that make it hard to find significant differences between the surfaces (Goossens and Rithalia, 2008, Sonenblum et al., 2014). Thus, the blood flow responses were not related to interface pressure and it was concluded that the interface pressure is not a good variable for studying the properties of blood flow in human tissue (Goossens and Rithalia, 2008). 


\section{Dynamics of blood flow}

\section{Skin vasculature}

The skin consists of the epidermis (the outermost layer), which is made up mostly of keratinocytes, and the dermis, which lies beneath the epidermis and consists mainly of connective tissue. The blood vessels, nerves, glands, and hair follicles are embedded in the thicker dermal tissue. The epidermis and dermis are connected by a basement membrane (Braverman, 2000, Braverman, 1997). The thickness of the epidermis is $0.60 \mathrm{~mm}-1.1 \mathrm{~mm}$, depending on the body sight, and the epidermal thickness of the buttock is $0.97 \pm 0.16 \mathrm{~mm}$ (Sandby-Moller et al., 2003).

The structure of the microcirculation consists of blood vessels smaller than $100 \mu \mathrm{m}$ in diameter, including arterioles, capillaries, and venules. It is organized in two horizontal plexuses, the upper and lower network (Figure 1). In the upper plexus, the capillary loops arise from the terminal arterioles in the superficial arterial plexus and are drained by the two levels of superficial venous plexuses. This upper network is located in the papillary dermis and is connected to the lower dermal-hypodermal plexus through ascending arterioles and descending venules (Braverman, 2000, Braverman, 1997).

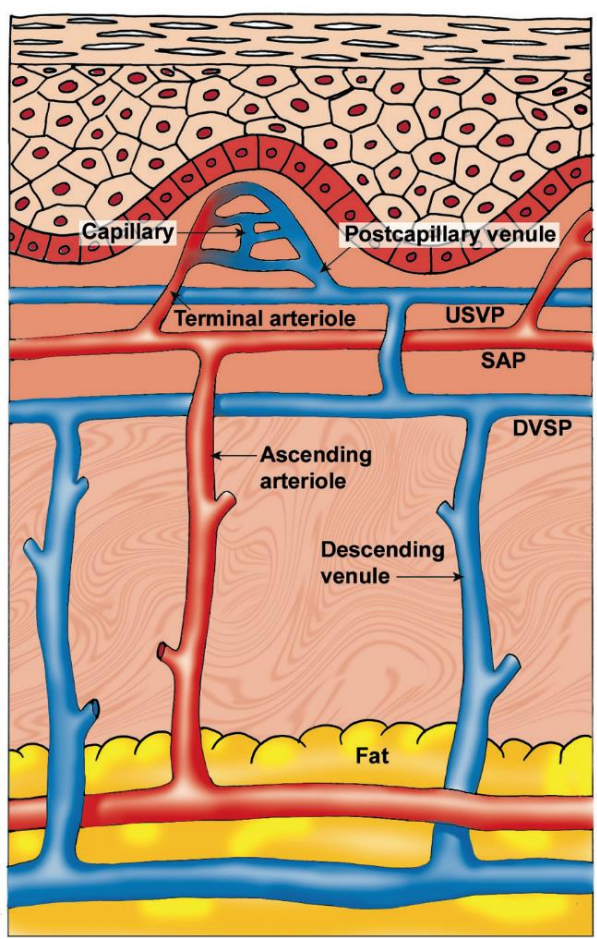

Figure 1. Blood supply of the dermis and epidermis. The upper network consists of the superficial arterial plexus (SAP), the upper superficial venous plexus (USVP), and the lower superficial venous plexus (DVSP). Reprinted with permission from Thorfinn, J Studies on sitting pressure and buttock microcirculation: aiming at developing an alarm in the prevention of pressure ulcers in patients with spinal cord injuries. Diss, Linköping University, p. 17, 2006. Illustration: Per Lagman, LiU Tryck, Linköping University, Sweden. 
The capillaries are known as exchange vessels of oxygen, nutrients and metabolites between the blood and the tissue cells. For this exchange to work, the capillary wall consists of a single layer of endothelial cells and a basement membrane. Normally, the blood flows through the capillaries due to alternating contraction and relaxation of the smooth muscle cells of the arterioles in a process called vasomotion. When the metabolic need is low, blood flows through a small part of the capillary network (Tuma et al., 2008).

\section{Regulation of skin blood flow}

The systems that control the smooth muscle cells in the blood vessels work centrally or locally, but their response is the same: constriction or dilatation of blood vessels. Vasoconstrictor nerves, vasodilator nerves, and humoral control provide optimal circulatory homeostasis such as cardiac output, blood pressure, venous flow, blood volume, and thermoregulation for the individual (Bertuglia et al., 1996).

During rest, the vascular tone is in a vasoconstricted state. Under normal conditions, increased blood flow results in vasodilation to maintain normal blood pressure. Endothelial dysfunction in vascular smooth muscle cells results in loss of vasodilatory function, and the vessels are not able respond to stimuli with sufficient dilation. Important mediators for normal vasodilation include nitric oxide (NO), prostaglandins (PG) and endothelial-derived hyperpolarizing factors (EDHF). Endothelial dysfunction is seen in several medical conditions such as cardiovascular disease, diabetes, infections, ischemia-reperfusion injury, and renal failure (Giles et al., 2012).

Non-noxious pressure on healthy skin induces prolonged vasodilation called pressure-induced vasodilation (PIV) (Fromy et al., 2012). This vasodilation is an appropriate adjustment of the vasomotor function to protect the tissue from ischemic damage and ulceration. PIV is mediated by substances such as NO, PG, and calcitonin gene-related peptide (CGRP) (Fromy et al., 1998, Fromy et al., 2000). Acid-sensing ion channel 3 (Asic3) is a neuronal sensor of PIV that releases CGRP and leads to a stimulation of endothelial NO (Fromy et al., 2012). When PIV activity is depressed in diabetics (Koitka et al., 2004), the elderly, and patients with neuropathy, even low pressure values can lead to a decrease in blood flow (Fromy et al., 2012).

When blood flow is released after a brief arterial occlusion, an increase in blood flow above baseline levels occurs (Cracowski et al., 2006). This is referred to as post-ischemic hyperemia, post-occlusive hyperemia, reactive hyperemia 
$(\mathrm{RH})$, or post-occlusive $\mathrm{RH}$ and depends on the following four major factors: metabolic vasodilators, endothelial vasodilators, the myogenic response, and sensory nerves (Binggeli et al., 2003, Cracowski et al., 2006, Larkin and Williams, 1993). Of the endothelial vasodilators, NO is not crucial for the response (Wong et al., 2003). These mediators have been studied in-depth, but their roles are not totally clear and there are conflicting results. However, sensory nerves and cytochrome expoxygenase metabolites are considered to be the main contributors to this response (Roustit and Cracowski, 2013).

PIV and RH are complex phenomena and have been investigated widely in the literature. Our understanding of these processes is incomplete, but models have been presented that try to synthesize the current knowledge (Figure 2) (Roustit and Cracowski, 2013). The sensory nerves are involved in the responses, and it is worth noting that there are potentially similar pathways, such as CGRP, that are involved in both PIV and RH. 


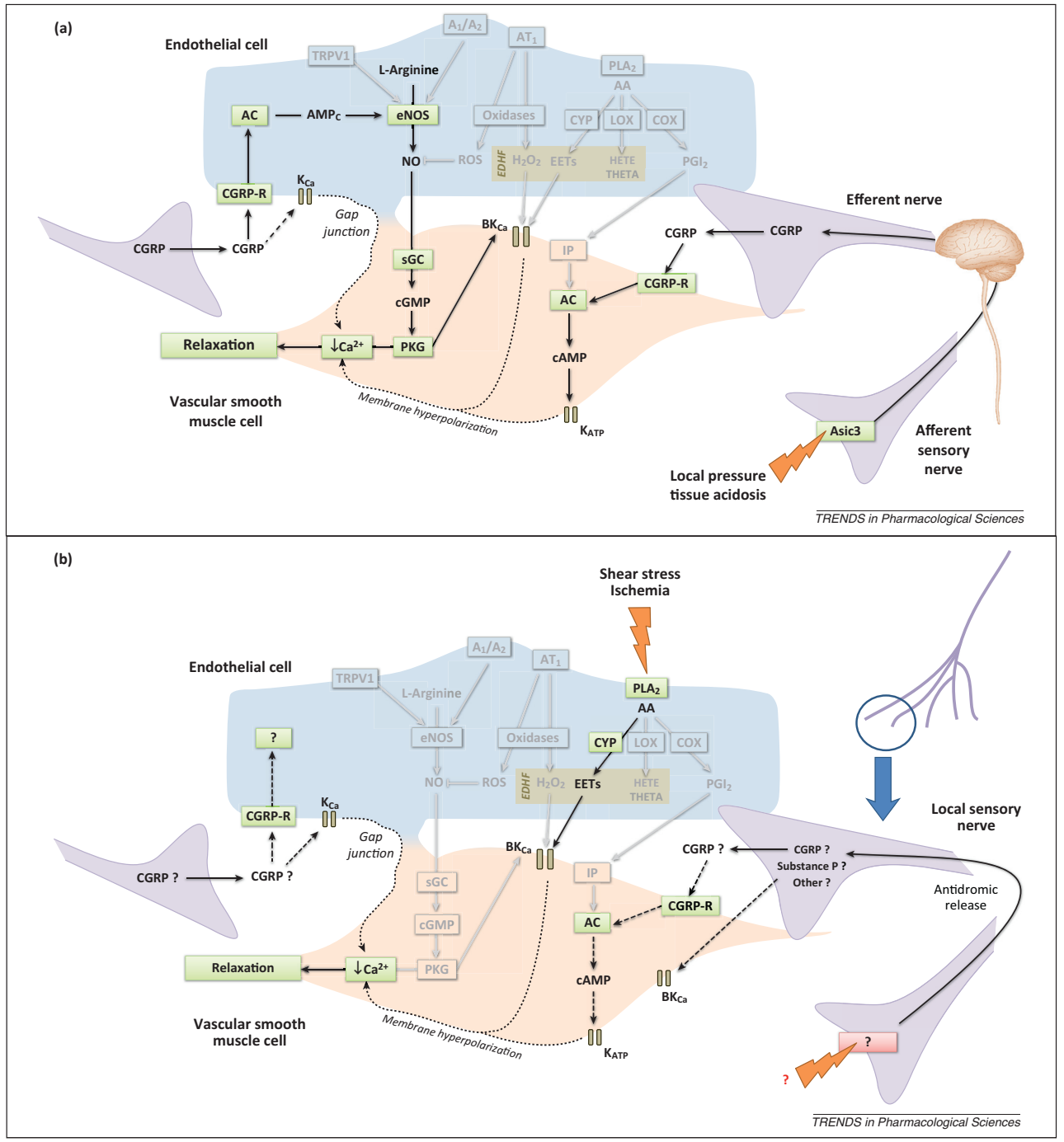

Figure 2. (a) Pathways involved in pressure-induced vasodilation. (b) Pathways involved in the reactive hyperemia. Grey arrows: not shown to be involved; broken arrows: putative pathways. Reprinted from Trends in Pharmacological Sciences, 34/7, Roustit, $M \mathcal{E}$ Cracowski, J-L, Assessment of endothelial and neurovascular function in human skin microcirculation, 373-383, 2013, with permission from Elsevier.

Abbreviations: $A 1 / A 2$, adenosine $A 1$ and $A 2$ receptors; $A A$, arachidonic acid; $A C$, adenylate cyclase; Asic 3 , acidsensing ion channel 3; AT1, angiotensin II receptor type 1 ; $B K_{c a}$, large-conductance $\mathrm{Ca}^{2+}$-activated $\mathrm{K}^{+}$channel; CGRP, calcitonin gene-related peptide; COX, cyclooxygenase; CYP, cytochrome P450; EETs, epoxyeicosatrienoic acids; eNOS, endothelial NO synthase; HETE, hydroxyleicosatetraenoic acid; IP, prostacyclin receptor; LOX, lipoxygenase; NO, nitric oxide; PGI2, prostacyclin; PKG, cGMP-dependent protein kinase or protein kinase G; PLA2, phospholipase A2; ROS, reactive oxygen species; $s G C$, soluble guanylyl cyclase; THETA, trihydroxyeicosatrienoic acid; TRPV1, transient receptor potential vanilloid receptor. 


\section{Blood flow measurements}

A number of optical techniques are used to assess the microcirculation. Optical microscopy-derived techniques such as videocapillaroscopy, orthogonal polarization spectral imaging, and side-stream dark field imaging all provide in vivo observations of the capillaries (Cutolo et al., 2008, Lupi et al., 2008, Treu et al., 2011). Different laser Doppler techniques such as laser Doppler flowmetry, laser Doppler imaging, and laser speckle contrast imaging provide a measurement of skin perfusion (Roustit and Cracowski, 2012). Photoplethysmography has been used for the indirect detection of blood flow pulsations by measuring blood volume changes (Allen, 2007). In this thesis, the laser Doppler flowmetry and photoplethysmography techniques have been used.

\section{Laser Doppler Flowmetry}

Laser Doppler flowmetry (LDF) has been used extensively for the evaluation of tissue perfusion in diabetes microangiopathy (Ek et al., 1987, Ek et al., 1984, Nilsson et al., 2003), pharmacological applications, and the diagnosis and evaluation of peripheral vascular diseases and skin diseases (Humeau et al., 2007). LDF has several advantages. It is relatively cheap, it has low operator bias because it is easy to perform, and it is well validated (Wright et al., 2006).

LDF uses laser (monochromatic) light that penetrates the skin. Moving objects in the tissue, e.g. red blood cells (RBCs), scatter the light, and this results in a frequency-broadened shift. The laser light is also scattered by static tissue, but this light is nonshifted and the differences between the two frequencies are detected as a photocurrent. This technique detects the shift in frequencies as an estimate of the perfusion and is presented in arbitrary numbers of volts. There is a linear relationship between perfusion and the velocity (vRBC) and the concentration (cRBC) of moving red blood cells (Nilsson et al., 2003, Nilsson et al., 1980, Nilsson et al., 1980): perfusion $=\left\langle\mathrm{vRBC}>{ }^{*} \mathrm{CRBC}\right.$.

\section{Photoplethysmography}

Photoplethysmography (PPG) is used in many different clinical applications, for example, monitoring physiological responses such as heart rate, blood pressure, cardiac output, respiration, and blood oxygen saturation (Allen, 2007). The PPG technique has also been used for vascular assessment when examining 
things such as arterial disease, arterial compliance and ageing, endothelial function, venous insufficiency, microvascular blood flow, and tissue viability. Another area is autonomic function measurements such as vasomotor function and thermoregulation, variability of heart rate and blood pressure, orthostasis, and neurological assessment. PPG is used in many commercially available medical devices due to its low price and use of small components. The PPG signal can be divided into two parts, an AC signal and a DC signal. The AC signal is a pulsatile signal that is synchronous with the heart rate. It correlates directly with the blood flow and reflects the arterial blood flow in the tissue (Lindberg and Oberg, 1991) and the orientation of the RBCs (Lindberg and Öberg, 1993, Naslund et al., 2006). The DC signal is a slowly varying signal reflecting total blood volume (Lindberg et al., 1991) and is used to measure vasomotor activity, respiration, and thermoregulation (Allen, 2007).

The light source of the PPG device emits light of a certain wavelength towards the area of investigation. Light that penetrates the tissue is absorbed, scattered, and reflected, and the reflected light can be detected by a photo detector. Tissue blood volume changes can be detected based on changes of the wavelength-dependent tissue optical absorption coefficient, and these are indirect measurements of blood flow. However, in rigid vessels such as those in bone, no blood volume changes are observed (Binzoni et al., 2013, Naslund et al., 2006) and the origin of the pulsatile signal from these vessels is suggested to be strictly related to variations in mean blood speed (Binzoni et al., 2013). The wavelength and distance between the light source and photo detector also determines the depth of penetration (Lindberg and Oberg, 1991). Green light is suitable for measurement of superficial skin blood flow, and infrared (IR) or near IR is suitable for measurements of the deep tissue (muscle) blood flow (Zhang et al., 2001).

\section{Linear analysis of blood flow}

Variations in blood flow are used to explore the regulatory mechanisms of blood flow as well as to measure functional changes during the development and treatment of diseases. Blood flow can be analyzed by linear and nonlinear methods to explore impaired mechanisms of microcirculation. Linear analysis includes time domain analysis - which quantifies the variations in blood flow to a given stimulus - and spectral analysis. Different studies of pathophysiological conditions have used linear analysis, and impaired blood flow has been observed in primary aging, diabetes, spinal cord injury, 
hypertension, congestive heart infarction, and risk for pressure ulcers. Spectral analysis explores the relative contributions from different frequencies to the blood flow signal and allows the contributions from the heartbeat, respiration, myogenic activity, neurogenic activity, NO-dependent vascular endothelial function, and NO-independent vascular endothelial function to be established (Liao et al., 2013).

Time domain analysis is a linear analysis that is performed to evaluate hyperemia in response to stimuli and includes the peak value of blood flow, time to peak, and the area under the curve of the hyperemic response (Cracowski et al., 2006, Jan et al., 2012). The peak value indicates how rapidly and extensively the vessels respond to ischemia, the time to peak relates to vascular resistance, and the area under the curve is considered to reflect the need for metabolic repayment following tissue ischemia (Liao et al., 2013). Blood flow responses can be normalized to the maximal blood flow value or the baseline. The skin temperature has a major impact on baseline blood flow, and maintaining an acceptable level of temperature can improve the reproducibility of the post-stimulus response (Liao et al., 2013). This thesis focused on the time domain analysis of blood flow changes at different depths during and after exposure of human sacral tissue to pressure. 


\section{AIMS}

The overall aim of this thesis was to combine optical methods into a system with the ability to simultaneously measure blood flow changes at different tissue depths. The goal of such a system was to reveal vascular mechanisms relevant to pressure ulcer etiology under clinically relevant conditions and in relation to the evaluation of pressure-redistribution support surfaces.

\section{Specific aims of the studies:}

To investigate the existence of sacral tissue blood flow at different depths in response to external pressure and compression in elderly individuals using a newly developed optical blood flow measurement probe prototype (Study I).

To evaluate a multi-parametric system combining laser Doppler flowmetry and photoplethysmography into a single probe, for the simultaneous measurement of blood flow at different depths in the sacral tissue when the tissue is exposed to external load. This new system will be used to facilitate the understanding of pressure ulcer formation (Study II).

To characterize pressure-induced vasodilation and reactive hyperemia at different sacral tissue depths in different populations under clinically relevant pressure exposure while lying in a supine position on a bed (Study III).

To explore the interaction between interface pressure and pressure-induced vasodilation and reactive hyperemia with different pressure-redistribution mattresses (Study IV). 



\section{METHODS}

\section{Design and setting}

This thesis is based on a positivistic approach and consists of four quantitative studies. These were all cross-sectional experimental studies with a prospective approach that measured blood flow responses related to baseline. Studies I and II were strictly descriptive and explored blood flow responses at different depths in 17 individuals. Study III added between-subject comparisons between three study groups. Study IV added within-subject comparisons using four different pressure-redistribution mattresses. The design of the blood flow measurements were longitudinal trend studies exploring PIV and RH.

A convenience sample of 17 participants was included in Studies I and II and were mainly recruited through a non-profit organization in the local area. The recruitment of non-patients to Studies III and IV was performed consecutively in informal ways. Everyone already participating was asked if they knew someone who they thought might be interested in participating, and in such cases the participants passed on written information of the study and contact information to the potential participants. The patients were consecutively recruited from the departments of Acute Internal Medicine, Hand Surgery, Plastic Surgery and Burns, Geriatric Medicine, and Neurology at a university hospital in Sweden.

In Studies III and IV, a statistical power analysis was performed for sample size estimation (alpha $=.05$ and power $=0.80$ ), and the projected sample size was suggested to be 70 inpatients and 70 healthy individuals with the patients divided into two subgroups of those at low risk and those at high risk for pressure ulcer development. Due to the difficulties of including high-risk patients, the sample size was adjusted to 35 inpatients and no subgroups. The healthy group was age adjusted to match the patient group. In total, a convenience sample of 35 inpatients, 42 younger healthy individuals 18-65 years (YOUNG) and 38 older healthy individuals $\geq 65$ years (OLD) was included in the studies.

The main variables that were studied and the assessments that were performed in the different studies are shown in Table 1. 
Table 1. Overview of the main variables and the measurements in Studies I-IV.

\begin{tabular}{|c|c|c|c|c|}
\hline Study & Procedure & Outcome & Measurements & General variables \\
\hline I-IV & & & & $\begin{array}{l}\text { Age, sex, height, } \\
\text { weight, body mass } \\
\text { index, medical history, } \\
\text { current medication, } \\
\text { tobacco use, body } \\
\text { temperature, blood } \\
\text { pressure, pulse, heart } \\
\text { rhythm, room } \\
\text { temperature }\end{array}$ \\
\hline I & $\begin{array}{l}\text { Load on the } \\
\text { sacral tissue } \\
\text { while lying in a } \\
\text { supine position } \\
\text { on a solid } \\
\text { surface }\end{array}$ & $\begin{array}{l}\text { Existence of blood } \\
\text { flow, tissue } \\
\text { thickness, tissue } \\
\text { compression, } \\
\text { interface pressure, } \\
\text { contact area }\end{array}$ & $\begin{array}{l}\text { Tissue blood flow at } \\
1,2,8, \text { and } 20 \mathrm{~mm} \text {, } \\
\text { skin temperature, } \\
\text { ultrasound } \\
\text { measurements of } \\
\text { tissue thickness, } \\
\text { pressure distribution, } \\
\text { body-surface contact } \\
\text { area }\end{array}$ & \\
\hline II & $\begin{array}{l}\text { Load on the } \\
\text { sacral tissue } \\
\text { while lying in a } \\
\text { prone position } \\
\text { during } 37.5 \\
\mathrm{mmHg} \text { and } 50 \\
\mathrm{mmHg} \text { loads }\end{array}$ & $\begin{array}{l}\text { Relative change in } \\
\text { blood flow, existence } \\
\text { of RH }\end{array}$ & $\begin{array}{l}\text { Tissue blood flow at } \\
1,2,8 \text {, and } 20 \mathrm{~mm} \text {, } \\
\text { skin temperature }\end{array}$ & \\
\hline III & $\begin{array}{l}\text { Load on the } \\
\text { sacral tissue } \\
\text { while lying in a } \\
\text { supine position } \\
\text { on a standard } \\
\text { mattress }\end{array}$ & $\begin{array}{l}\text { Relative change in } \\
\text { blood flow, existence } \\
\text { of PIV and RH, } \\
\text { average pressure, } \\
\text { peak pressure, probe } \\
\text { pressure }\end{array}$ & $\begin{array}{l}\text { Tissue blood flow at } \\
1,2 \text {, and } 10 \mathrm{~mm} \text {, skin } \\
\text { temperature, pressure } \\
\text { distribution }\end{array}$ & $\begin{array}{l}\text { History of pressure } \\
\text { ulcer, risk of pressure } \\
\text { ulcer development }\end{array}$ \\
\hline IV & $\begin{array}{l}\text { Load on the } \\
\text { sacral tissue } \\
\text { while lying in a } \\
\text { supine position } \\
\text { on a standard } \\
\text { hospital } \\
\text { mattress and } 3 \\
\text { different } \\
\text { pressure- } \\
\text { redistribution } \\
\text { mattresses }\end{array}$ & $\begin{array}{l}\text { Relative change in } \\
\text { blood flow, existence } \\
\text { of PIV and RH, } \\
\text { average pressure, } \\
\text { peak pressure, probe } \\
\text { pressure }\end{array}$ & $\begin{array}{l}\text { Tissue blood flow at } \\
1,2 \text {, and } 10 \mathrm{~mm} \text {, skin } \\
\text { temperature, pressure } \\
\text { distribution }\end{array}$ & $\begin{array}{l}\text { History of pressure } \\
\text { ulcer, risk of pressure } \\
\text { ulcer development }\end{array}$ \\
\hline
\end{tabular}

RH: reactive hyperemia, PIV: pressure-induced vasodilation 


\section{Participants}

The non-patients in the different studies were chosen to mirror a population as close as possible to a normal population and are referred to from here on as healthy individuals. They all described themselves as healthy although some had medical conditions, and they all lived an independent and active life in their own homes with no home-help services. The patients were all admitted to the university hospital due to medical conditions, but their conditions were stable and none were on oxygen treatment. They were mobile to various degrees, but all were at least able to stand upright and to participate in active transfer between experiments with the assistance of two persons. The patients were included in the studies only after medical approval from the responsible physician. An overview of the selections of participants is presented in Table 2. By only including subjects with normal body temperature, the influences of increasing metabolic demand on the tissue due to fever could be controlled for.

Table 2. Subject selection for Studies I-IV.

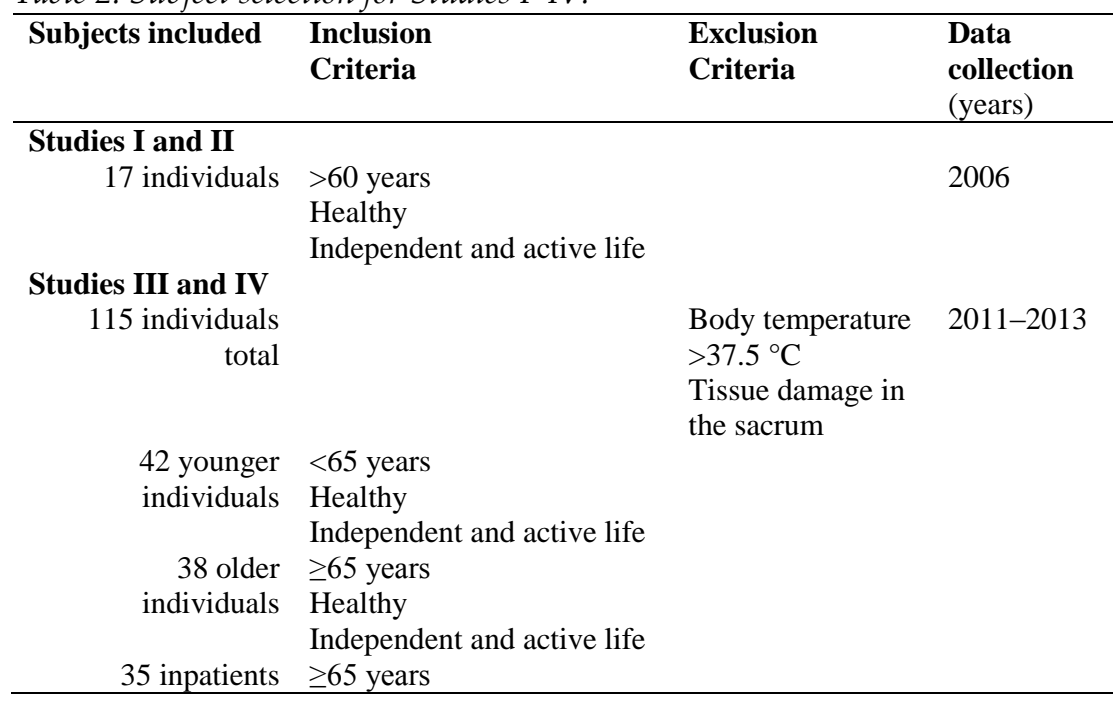

Because the participants in Studies III and IV were consecutively included, it is not known how many persons declined participation. Due to the informal way in which the healthy individuals were recruited, no one who received written information declined participation. Among the patients who were deemed suitable for participation according to the ward staff, approximately two thirds declined participation, almost all due to a too demanding study design. 


\section{Procedures}

\section{Studies I and II}

In the first test situation, presented in Study I, ultrasound measurements of the tissue thickness in the sacral area were performed in both loaded and unloaded tissue. The measurements were performed by a highly experienced technician. A point $2-3 \mathrm{~cm}$ from the subject's medial sacral crest was marked as the point of measurement. The participant lay in a supine position on a test bench consisting of a wooden plate with a $10 \mathrm{~cm} \times 10 \mathrm{~cm}$ hole in it. The ultrasound transducer was led through the hole, and measurements of the unloaded tissue were performed. A Plexiglas plate was then fitted in the hole in line with the surface of the bench and measurements of the subject's tissue thickness - loaded with their own body weight - were performed.

In the second test situation, blood flow measurements were performed. All measurements were performed at the same time of day and in the same room. At first, the subject rested in a supine position for $15 \mathrm{~min}$ on the test bench after which the heart rate, body and skin temperature, and blood pressure were noted. The subject was then placed in a prone position and the probe was fixed by double-adhesive, non-allergenic tape at the sacral area to be measured (Figure 3a).

After another ten minutes of rest, the blood flow measurements in the prone position began. The baseline data were used in both Studies I and II. The baseline measurement began with a five-minute period of measurement while the tissue was unloaded. A period of five minutes started after loading with a $37.5 \mathrm{mmHg}$ weight onto the sacral tissue. The tissue was then unloaded for five minutes followed by five minutes of loading with a $50.0 \mathrm{mmHg}$ weight. This was followed by five minutes of unloaded tissue. These results are presented in Study II. The weight was laterally fixed, but horizontal movement was possible so that the weight was not affected by breathing movement.

After the loading session, the probe was fixed to the test bench even with the surface and the subject was turned to a supine position to rest for ten minutes (Figure $3 b$ ). Five minutes of loading with the subject's own body weight followed, and blood flow and interface pressure were recorded. These measurements are presented in Study I. 
(a)
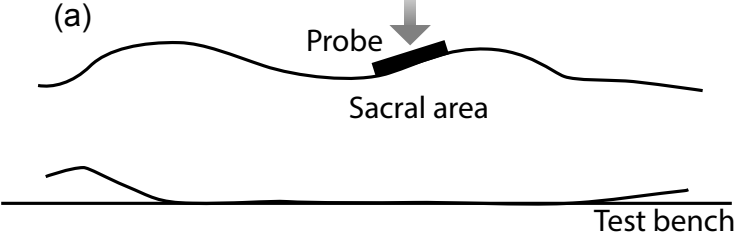

(b)

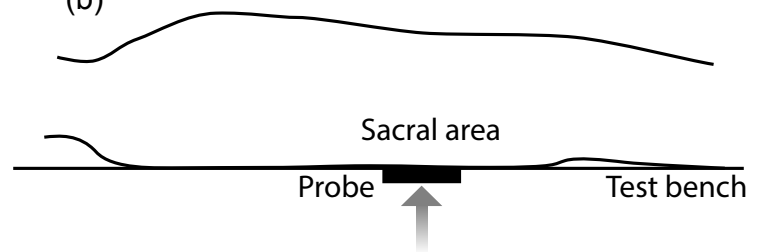

Figure 3. Figure (a) shows a subject in a prone position and Figure (b) shows a subject in a supine position when performing the measurements. Gray arrows indicate exposure of pressure. Illustration: Per Lagman, LiU Tryck, Linköping University, Sweden.

\section{Studies III and IV}

The data collections for Studies III and IV were performed during one measurement session using four different mattresses, one standard hospital foam mattress, two types of constant low pressure support surfaces (i.e. foam mattresses), and one alternating pressure-redistributing mattress. The standard hospital mattress and one of the pressure-redistribution foam mattresses were made of high-resilience polyurethane foam with different specified levels of functional support. These are referred to as the standard mattress and the HRP foam mattress, respectively. The third mattress was a non-powered air filled foam mattress with an outer layer of visco-elastic (V-E) foam, or memory foam, and beneath the foam layer, horizontal air sectors. V-E foam is a high-density foam that reacts to heat and adjusts to fit snugly against the body and has specified high support function. This mattress is referred to as the V-E foam/air mattress. The fourth mattress was an alternating pressure mattress. The principle of alternating pressure is that rows of air-filled cells are alternately inflated and deflated such that different body areas are exposed to pressure and for shorter lengths of time.

All participants participated in one measurement session that was carried out in a separate room at the hospital. The measurement probe was fixed with adhesive tape to the sacral area as identified by palpation of the medial sacral crest. Each subject was placed on the four mattresses in a random order by drawing lots. The subject was placed on their side on the first mattress and acclimatized to a horizontal position for 15 minutes (Figure 4). At the end of the 
acclimation period, the subject's blood pressure, pulse, heart rhythm, and body temperature were noted along with the ambient room temperature. The subjects were asked to avoid moving or speaking during the measurement session in order to minimize movement artifacts.

The first baseline measurement period was a 5 min measurement with the subject still lying on their side with the sacral tissue unloaded. The patient then rolled over into a supine position and a measurement period of 10 minutes followed with the sacral tissue loaded. After the supine measurement period was completed, the subject was placed back on their same side for a $10 \mathrm{~min}$ postload measurement period with the sacral tissue unloaded. When the three measurement periods were completed, the subject was transferred to the next mattress with as little effort as possible. A 2 min acclimatization period on the new mattress was performed followed by a new baseline period and so on. The mean sacral pressure and peak sacral pressure were noted at the end of the supine period for the three foam mattresses. The 10 minute load periods were chosen because the manufacturers of these types of mattresses state that the foam needs to acclimate for at least 7-8 $\mathrm{min}$ for it to have maximal performance. The post-load period was chosen according to common practice based on observations that RH lasts approximately for the same length of time as the loading period.

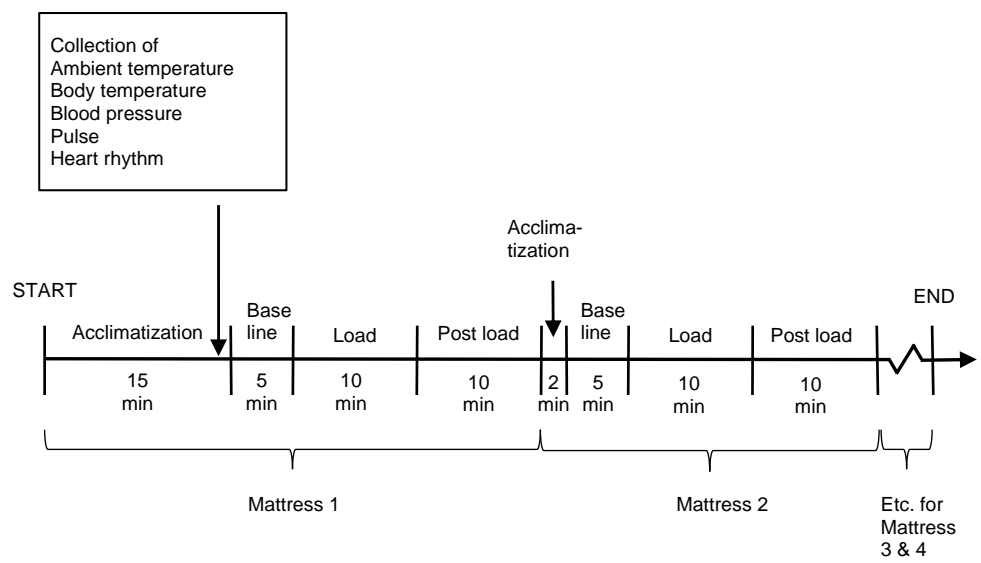

Figure 4. Schematic description of the measurement session in Studies III and IV. Measurements of blood flow, skin temperature and interface pressure were recorded continuously during the whole session.

When the subject was placed on the alternating mattress, their body position was adjusted so that the measurement probe was placed in the middle of an air cell in static mode at the beginning of the period in the supine position. The 
alternating mode was then started and the point in time and the order in which the cells were maximally inflated and deflated was noted. The time period for one complete cycle of an inflated and a deflated cell was approximately 10 minutes.

\section{Measurements}

\section{The optical system}

In this thesis, an optical system consisting of LDF and PPG instruments integrated into a single probe was used in the different experimental setups.

In Studies I and II a HeNe laser with a wavelength of $632.8 \mathrm{~nm}$ (PeriFlux Pf2b, Perimed, Järfälla, Sweden) was used. In Studies III and IV, a solid-state diode laser (PF 5001 Main Unit, Perimed, Järfälla, Sweden) with a wavelength of $780 \mathrm{~nm}$ was used together with a probe (Perimed 415-242 SPP, Perimed, Järfälla, Sweden) with a fiber separation of $0.25 \mathrm{~mm}$.

The PPG instrument was developed at the Department of Biomedical Engineering (Linköping University, Linköping, Sweden) and consisted of a three-channel (Studies I and II) or a two-channel (Studies III and IV) instrument. Green light $(560 \mathrm{~nm})$ and near infrared (IR) light $(810 \mathrm{~nm})$ were used for penetrating the tissue to different depths. A prototype probe was developed by the research team and fabricated by the engineers at the department for Studies I and II, and the probe was further elaborated upon for use in Studies III and IV in clinically relevant conditions lying in bed.

\section{The prototype probe}

The prototype probe consisted of three pairs of light-emitting diodes (LEDs) placed symmetrically around a photo detector (Figure 5). The distance from the photo detector was $5 \mathrm{~mm}$ for the green LEDs and $10 \mathrm{~mm}$ and $25 \mathrm{~mm}$ for the IR LEDs. This combination of wavelengths and distances gave penetration depths of approximately $2 \mathrm{~mm}, 8 \mathrm{~mm}$, and $20 \mathrm{~mm}$. One laser Doppler optic fiber was integrated and inserted between the IR LEDs to give a measurement depth of less than $1 \mathrm{~mm}$. All of the components of the prototype probe were integrated into a stiff silicon plate measuring $10 \mathrm{~cm} \times 10 \mathrm{~cm}$. 


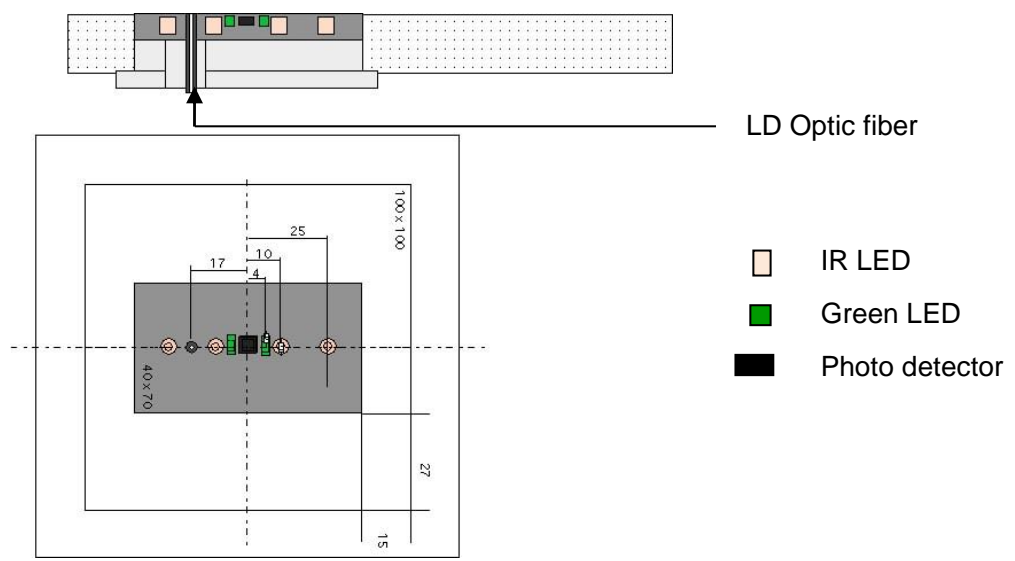

Figure 5. Schematic view of the optical probe used in Studies I and II with all of the components: the LEDs symmetrically placed around the photo detector and a laser Doppler fiber inserted between the IR LEDs. All measurements are in millimeters. Illustration: Jimmie Hagblad, Mälardalen University, Västerås, Sweden.

\section{The elaborated probe}

The optical components in the elaborated probe consisted of six green LEDs placed $3.4 \mathrm{~mm}$ from the photo detectors and four IR LEDs placed $25.0 \mathrm{~mm}$ from the photo detectors (Figure 6) to measure tissue blood flow at depths of approximately $2 \mathrm{~mm}$ and $10 \mathrm{~mm}$, respectively (Hagblad et al., 2010). The components were embedded in a thin, flexible silicon plate $(10 \mathrm{~cm} \times 10 \mathrm{~cm})$ with the edges beveled to avoid any tissue stress. The LDF probe was inserted into the silicon plate and a highprecision aperture in the plate put the LDF probe exactly in line with the plate surface. The positions of the optical components and the LDF probe were chosen to avoid any interference between the two optical techniques. A temperature sensor (Perimed, PF442, Perimed, Järfälla, Sweden) was placed in an additional aperture to complete the

IR LED

- Green LED

Photo detector Place for LDF/Temp

Figure 6. The integrated probe used in Studies III and IV with the positions of the PPG optical components, the LDF optical fiber, and the temperature sensor. Illustration: Per Lagman, LiU Tryck, Linköping University, Sweden. measurement system. 


\section{Other measurements}

The sacral tissue was measured in Study I with a digital ultrasound system (HDI 5000, Philips Medical Systems, ATL Ultrasound, Bothell, WA, USA) with a linear transducer (L7-4). The sacral crest was located visually and the tissue thickness between the skin surface and the bone was calculated directly in the system (Figure 7).

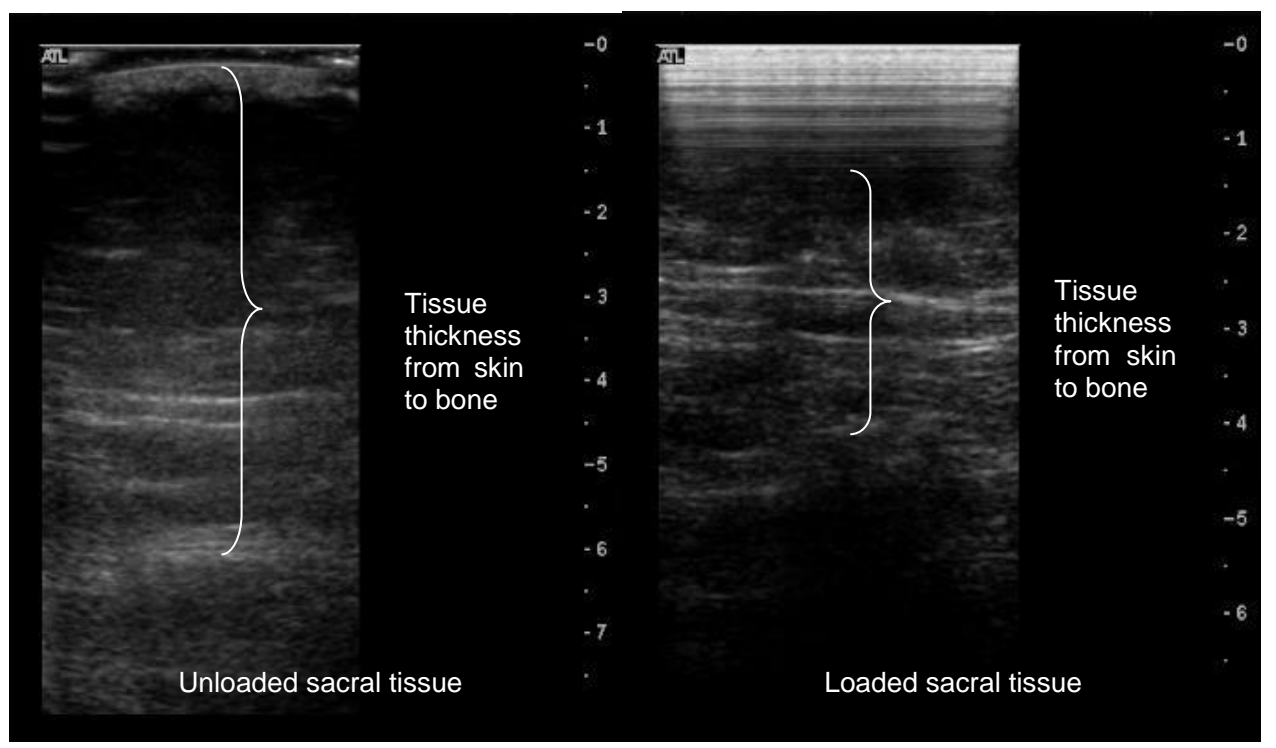

Figure 7. Ultrasound measurements of tissue thickness in unloaded and loaded sacral tissue in one individual.

A pressure mapping system (Xensor Pressure Mapping System X236, Anatomic Sitt, Norrköping, Sweden) was used in Studies I, III and IV to measure pressure and contact area in the sacral area. The system identified the subject's contact area with the surface, the pressure distribution, the mean pressure value, and the maximum pressure value of the contact area. It consisted of an underlay (45 $\mathrm{cm} \times 45 \mathrm{~cm}$ ) with integrated pressure sensors (4 sensors/square inch) with the ability to measure pressure ranging from $10 \mathrm{mmHg}$ to $220 \mathrm{mmHg}$ (Figure 8).

To measure interface pressure over the area where the measurement probe was located - referred to as the sacral probe pressure in Studies III and IV - a thin and flexible pneumatic pressure transmitter was used. It was fastened on the outside of the optical probe and located between the probe and the mattress during load. It was connected to a digital manometer that was developed in our department. 


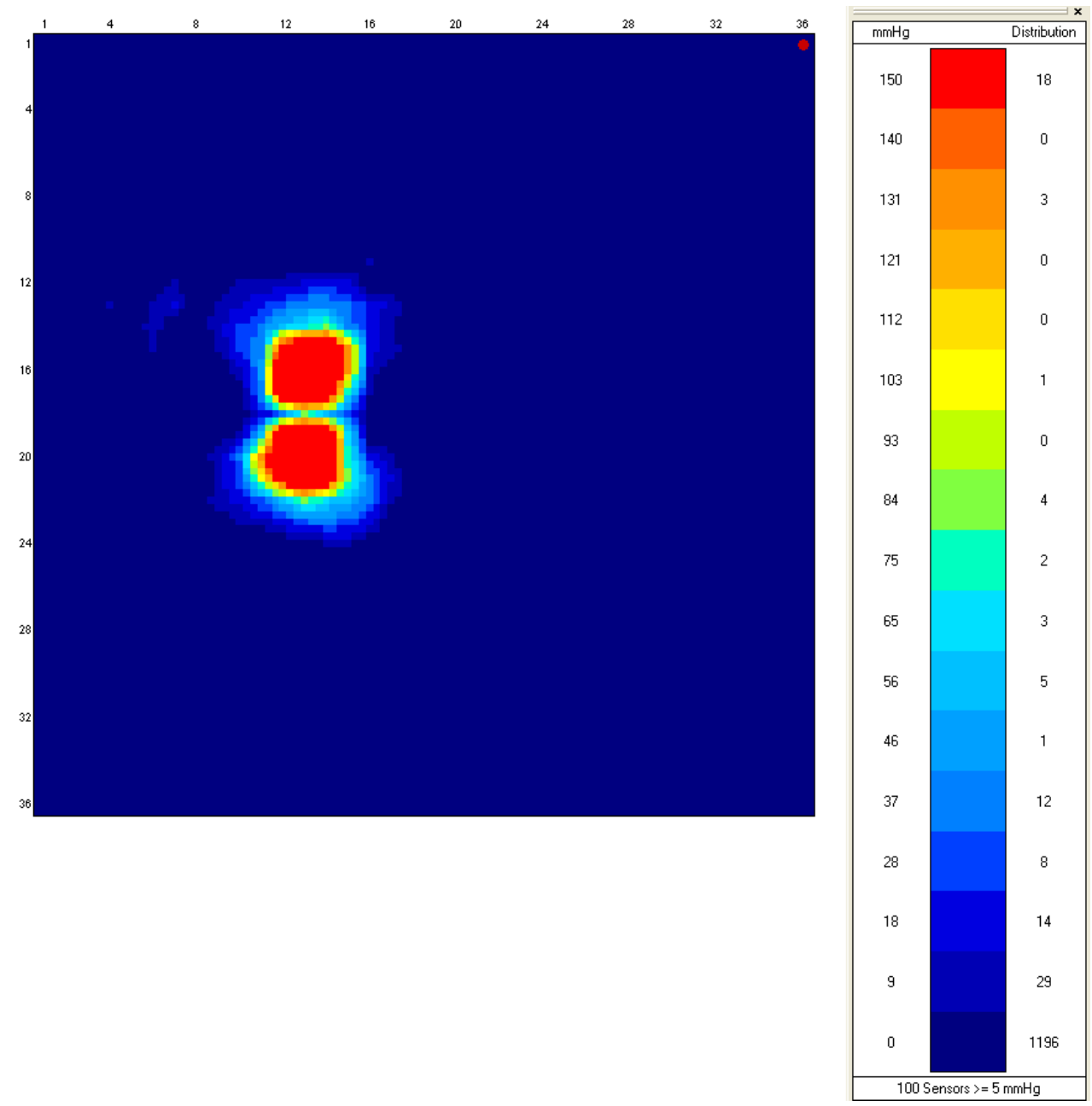

Figure 8. Example of data from the pressure mapping system showing the pressure distribution and contact area in the sacral area in one subject. The image is representative of those obtained in Study I.

The patients' risk for developing pressure ulcers was assessed in Studies III and IV with the Risk Assessment Pressure Ulcer Scale (RAPS) in collaboration with the ward nurse. The scale consists of the following 10 variables: general physical condition, activity, mobility, skin moisture, food intake, fluid intake, sensory perception, friction and shear, body temperature, and S-albumin levels (Lindgren et al., 2002). Patients with a total score of 29 points or lower (out of a maximum of 35) were considered to be at risk for pressure ulcers (Kallman and Lindgren, 2014, Lindgren et al., 2002). 
In all studies, blood pressure was measured with a manual cuff (Spiedel \& Keller, Jungingen, Germany), body temperature was measured with a Thermoscan 6022 (Braun, Kronberg, Germany), and room temperature was measured with a digital thermometer (type 565, Schwille elektronik, Kircheim, Germany). Skin temperature in Studies I and II was measured with an IR thermometer (Raytek Raynger ST, Santa Cruz, CA, USA).

\section{Data analysis}

The following formulas and definitions were used to define variables in the thesis. The mean arterial pressure (MAP) (Study I) was calculated as a function of diastolic pressure (DP) and systolic pressure (SP): $\mathrm{MAP}=\mathrm{DP}+(\mathrm{SP}-\mathrm{DP}) / 3$. The body mass index (BMI) (Studies I-IV) was calculated as BMI = weight in kilograms / (height in meters) ${ }^{2}$. The WHO BMI classification of underweight is $\mathrm{BMI}<18.5$, normal range of $\mathrm{BMI}$ is between 18.5 and 24.99, and overweight is $\mathrm{BMI} \geq 25.0$ (WHO, 2004).

\section{Studies I and II}

Blood flow was recorded with a sampling frequency of $75 \mathrm{~Hz}$ (Labview 6.1, National Instruments, Kista, Sweden) and analyzed with an in-housedeveloped program (IMT, Linköping University, Linköping, Sweden). Both the AC signal and the DC signal were recorded and analyzed, but only the data from the AC signal were used in this thesis. The blood flow was assessed as occluded in Study I when there were no pulsations in the AC signal from the PPG instrument and the perfusion value from the LDF instrument was close to zero and without pulsations. The blood flow in Study II was calculated by computing the mean amplitudes for the PPG AC signal and the mean values for the LDF signal. The computed time periods were between $15 \mathrm{~s}$ and $20 \mathrm{~s}$ and were chosen based on the quality of the signal.

The tissue thickness in Study I was calculated directly in the ultrasound system, and the mean value from three different images in each situation was registered. The pressure analysis of the Xensor underlay in Study I was performed with the software provided with the system to collect pressure distribution and body-surface contact area in the sacrum. 


\section{Studies III and IV}

The pressure analysis of the Xensor underlay was performed with the software provided with the system to collect the mean interface pressure (average sacral pressure) and maximum interface pressure (peak sacral pressure). The Xensor underlay was not used on the alternating mattress due to the hammock effect in which the underlay might impair the load-distributing properties of the alternating mattress.

The LDF and PPG blood flow measurements, the skin temperature, and the sacral probe pressure were collected at a sampling frequency of $75 \mathrm{~Hz}$ using the Labview software (Labview 6.1, National Instruments, Kista, Sweden). Measurement intervals of 30 seconds in length were analyzed using Matlab software 2013a (The Mathworks, Natick, MA) with an in-house-developed script. The selected measurement periods were at baseline, at the end of the 10 min supine period for the foam mattresses or at the noted time periods for the inflated and deflated cell for the alternating mattress, and then directly after unloading ( $\left.t_{0}\right)$ and at 1 minute $\left(t_{1}\right), 2$ minutes $\left(t_{2}\right), 5$ minutes $\left(t_{5}\right)$, and 10 minutes $\left(t_{10}\right)$ after unloading to cover the post-load period (Figure 9$)$. The mean values of skin temperature and blood flow at the selected periods were calculated, and the blood flow was presented as the relative change in percent from the baseline measurement. The sacral probe pressures were analyzed at baseline and in the supine position and were converted by linear equation from volts into millimeters of mercury $(\mathrm{mmHg})$.

The overall blood flow (BFoverall) in the post-load period was calculated as the area under the curve with relative change (\%) on the y-axis and time ( $\mathrm{min}$ ) on the $x$-axis and the values given from to to $t_{10}$ (Figure 9). The maximum blood flow $\left(\mathrm{BF}_{\max }\right)$ during the post-load period $\left(\mathrm{t}_{0}-\mathrm{t}_{10}\right)$ was noted as well as when it occurred (Timemax). PIV was defined as a positive relative change in blood flow during load (BFload). A hyperemic response in the post-load period was considered to be present if $\mathrm{BF}_{\max }$ was $5 \%$ over baseline or higher. $\mathrm{RH}$ was defined as a lack of PIV and the presence of a hyperemic response. 


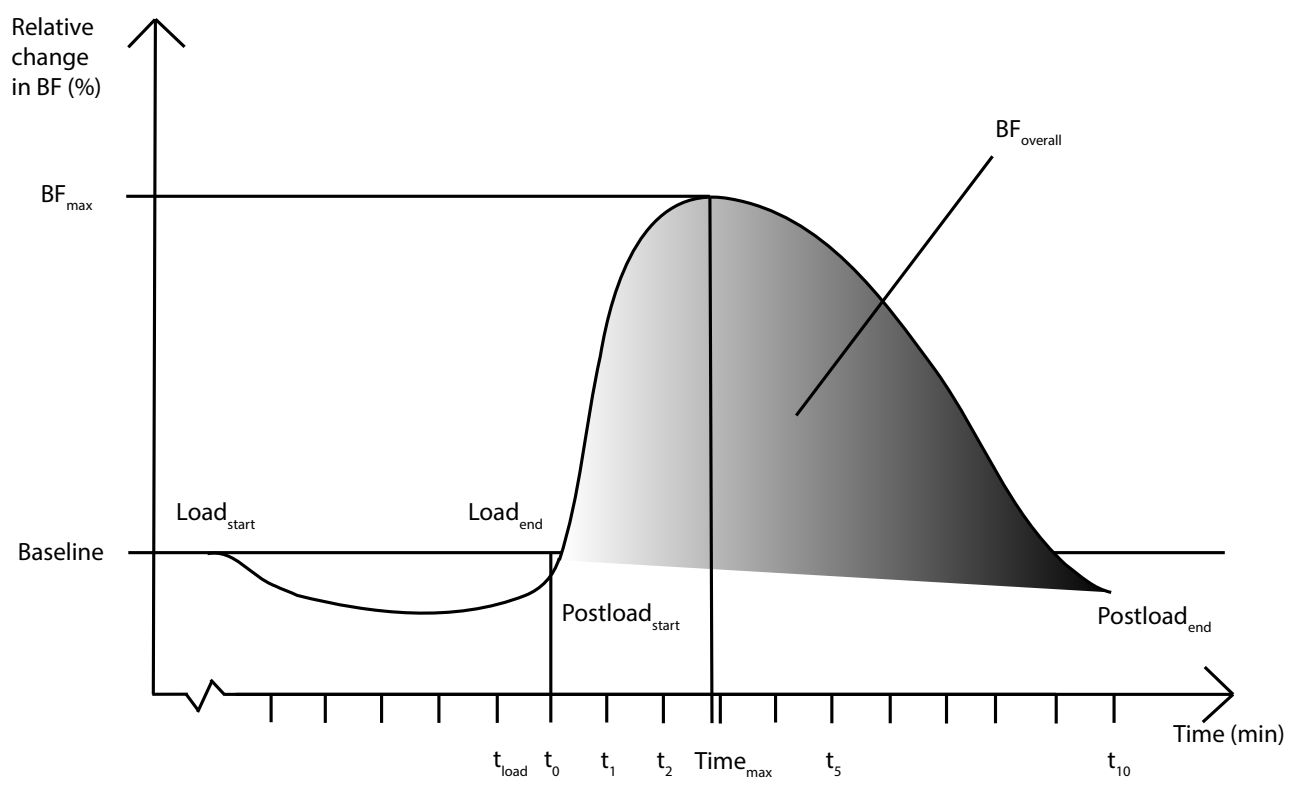

Figure 9. Schematic description of the different variables analyzed. The start of the measurement period in the supine position $\left(\right.$ Load $_{\text {start }}$ ), the end of the measurement period in the supine position $\left(\right.$ Load $\left._{\text {end }}\right)$, the start of the post-load period (Postloadstart), and the end of the postload period (Postloadend) are shown. Blood flow was analyzed at baseline, at the end of the supine period ( $\left.t_{\text {load }}\right)$, directly after unloading $\left(t_{0}\right)$, and at 1 minute $\left(t_{1}\right), 2$ minutes $\left(t_{2}\right), 5$ minutes $\left(t_{5}\right)$, and 10 minutes ( $\left.t_{10}\right)$ after unloading. The interface pressure was registered at baseline and at tload. Blood flow was presented as the relative change in percent from the related baseline. The overall blood flow (BFoveral $)$ in the post-load period was calculated as the area under the curve. The maximum value $\left(B F_{\max }\right)$ from to to $t_{10}$ was noted as well as the time when it occurred

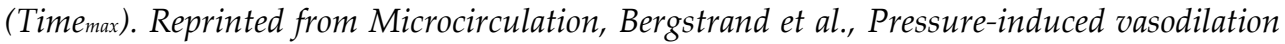
and reactive hyperemia at different depths in sacral tissue under clinically relevant conditions, 2014 [Epub ahead of print], with permission from John Wiley $\mathcal{E}$ Sons Ltd.

The order of the inflated and deflated cells in the alternating mattress was not known prior to the analysis of the data. The analysis of the blood flow responses in the post-load period for the alternating mattress (Study IV) was only performed in those cases when the deflated cell was followed by the inflated cell. This was to avoid the post-load period starting during the deflated cell because this could influence the results.

Subjects with an absence of PIV and RH were considered to have a highrisk blood flow response due to pressure exposure. PIV and RH are both linked separately with the risk of pressure ulcer development, and subjects who are particularly vulnerable to pressure exposure have been shown to have depressed or absent responses (Fromy et al., 2010, Koitka et al., 2004, Schubert 
and Fagrell, 1991). The implication is that subjects who have an absence of both PIV and RH might be at even higher risk of developing pressure ulcers.

\section{Statistics}

An overview of the different statistical tests is presented in Table 3. The background data in the different studies were distributed normally and are, therefore, presented in terms of mean \pm standard deviation. A p-value $<0.05$ was considered to be significant. All statistical analyses were performed using PASW Statistics versions 13.0-15.0 (Studies I and II) and 21.0 (Studies III and IV) (IBM SPSS Inc., Chicago, IL, USA).

Sub-analysis of the background data (Studies I and II) was performed because five of the participants had a cardiovascular diagnosis. No significant differences were found between the participants without diagnosis and those with diagnosis, and the material in the thesis is, therefore, presented as one group.

Imputation was carried out for isolated missing blood flow values in the post-load period (Studies III and IV). When the missing blood flow data were at $t$, the imputation was the blood flow at $t_{1}$. When the missing blood flow data occurred at $t_{1}$ or $t_{5}$, the imputation was the mean value of the blood flow at the previous and following point in time. When the missing blood flow data were at $t_{10}$, the imputation was the blood flow at $t_{5}$. The imputation included $2.7 \%$ of the total data.

In Study III, a linear mixed model analysis was performed to compare $\mathrm{BF}_{\text {overall }}$ (model 1) and $\mathrm{BF}_{\max }$ (model 2) between study groups and tissue depths after adjusting for confounding variables. The variables were tested for homogeneity of variances. Fixed effect variables were measurement depth, sex, age, study group, diastolic blood pressure, pulse, BMI, average sacral pressure, peak sacral pressure, sacral probe pressure, skin temperature during load, and the number of medications being taken. BFload was added as a fixed effect variable. A manual stepwise model analysis was performed. All fixed effect variables were included in the first model, and the variables with the highest $\mathrm{p}$ values were removed from the next step. For the final models, only the variables that had confounding effects or were significant on their own were included. The medications were tested as confounding variables in the final models (models 1 and 2) both separately and grouped into cardiac and diabetic drugs. 
Table 3. Study-specific statistical tests.

\begin{tabular}{|c|c|c|c|c|c|}
\hline \multirow[b]{2}{*}{ Method } & \multirow[b]{2}{*}{ Data } & \multicolumn{4}{|c|}{ Application } \\
\hline & & Study I & Study II & Study III & Study IV \\
\hline $\begin{array}{l}\text { Dependent } \\
\text { sample t-test }\end{array}$ & $\begin{array}{l}\text { Continuous, } \\
\text { two groups }\end{array}$ & $\begin{array}{l}\text { Skin } \\
\text { temperature } \\
\text { pre- and } \\
\text { post-load, } \\
\text { loaded and } \\
\text { unloaded } \\
\text { tissue } \\
\text { thickness }\end{array}$ & $\begin{array}{l}\text { Skin } \\
\text { temperature } \\
\text { pre- and } \\
\text { post-load }\end{array}$ & & \\
\hline $\begin{array}{l}\text { Friedman's } \\
\text { ANOVA } \\
\text { (Cochran's } \\
\text { test): } \\
\text { McNemar test } \\
\text { with } \\
\text { Bonferroni } \\
\text { correction for } \\
\text { post-hoc } \\
\text { comparisons }\end{array}$ & $\begin{array}{l}\text { Dichotomous, } \\
\text { several } \\
\text { related groups }\end{array}$ & & & $\begin{array}{l}\text { Proportion of } \\
\text { subjects with a } \\
\text { lack of PIV at } \\
\text { different tissue } \\
\text { depths }\end{array}$ & $\begin{array}{l}\text { Proportions of } \\
\text { subjects with a } \\
\text { lack of PIV on } \\
\text { the different } \\
\text { mattresses and } \\
\text { at different } \\
\text { tissue depths }\end{array}$ \\
\hline $\begin{array}{l}\text { Independent } \\
\text { sample t-test }\end{array}$ & $\begin{array}{l}\text { Continuous, } \\
\text { two groups }\end{array}$ & & $\begin{array}{l}\text { Age and } \\
\text { BMI } \\
\text { between } \\
\text { genders }\end{array}$ & $\begin{array}{l}\text { Subjects with and } \\
\text { without high-risk } \\
\text { BF responses } \\
\text { with regard to the } \\
\text { number of } \\
\text { medications and } \\
\text { tobacco users } \\
\text { with non-users } \\
\text { with regard to BF } \\
\text { responses during } \\
\text { load and the post- } \\
\text { load period }\end{array}$ & \\
\hline Levene's test & $\begin{array}{l}\text { Continuous, } \\
\text { more than } \\
\text { two groups }\end{array}$ & & & $\begin{array}{l}\text { Homogeneity of } \\
\text { variances in } \\
\text { ANOVA }\end{array}$ & $\begin{array}{l}\text { Homogeneity } \\
\text { of variances in } \\
\text { ANOVA }\end{array}$ \\
\hline $\begin{array}{l}\text { Linear mixed } \\
\text { model } \\
\text { analysis }\end{array}$ & $\begin{array}{l}\text { Ordinal, } \\
\text { continuous }\end{array}$ & & & $\begin{array}{l}\text { Compare } \mathrm{BF}_{\text {overall }} \\
\text { (model 1) and } \\
\mathrm{BF}_{\max } \text { (model 2) } \\
\text { between study } \\
\text { groups and tissue } \\
\text { depths after } \\
\text { adjusting for } \\
\text { confounding } \\
\text { variables }\end{array}$ & \\
\hline $\begin{array}{l}\text { Mauchly's } \\
\text { test }\end{array}$ & $\begin{array}{l}\text { Continuous, } \\
\text { more than } \\
\text { two groups }\end{array}$ & & & $\begin{array}{l}\text { Assumption of } \\
\text { sphericity in } \\
\text { repeated } \\
\text { measures } \\
\text { ANOVA }\end{array}$ & $\begin{array}{l}\text { Assumption of } \\
\text { sphericity in } \\
\text { repeated } \\
\text { measures } \\
\text { ANOVA }\end{array}$ \\
\hline
\end{tabular}


Table 3 (Continued). Study-specific statistical tests.

\begin{tabular}{|c|c|c|c|c|c|}
\hline \multirow[b]{2}{*}{ Method } & \multirow[b]{2}{*}{ Data } & \multicolumn{4}{|c|}{ Application } \\
\hline & & Study I & Study II & Study III & Study IV \\
\hline $\begin{array}{l}\text { McNemar chi- } \\
\text { squared test }\end{array}$ & $\begin{array}{l}\text { Nominal, } \\
\text { two related } \\
\text { groups }\end{array}$ & $\begin{array}{l}\text { Existing BF } \\
\text { in unloaded } \\
\text { and loaded } \\
\text { tissue }\end{array}$ & & & \\
\hline $\begin{array}{l}\text { One way } \\
\text { ANOVA } \\
\text { (unequal } \\
\text { homogeneity: } \\
\text { Welch test of } \\
\text { Equality of } \\
\text { Means): } \\
\text { Tukey's HSD } \\
\text { test or Games- } \\
\text { Howell test for } \\
\text { post-hoc } \\
\text { comparisons }\end{array}$ & $\begin{array}{l}\text { Continuous, } \\
\text { more than } \\
\text { two groups }\end{array}$ & & & $\begin{array}{l}\text { Vital signs, } \\
\mathrm{BF}_{\text {load, }} \text { skin } \\
\text { temperature, } \\
\text { and sacral } \\
\text { pressure during } \\
\text { load between } \\
\text { study groups }\end{array}$ & $\begin{array}{l}\text { Differences } \\
\text { between the study } \\
\text { groups with regard } \\
\text { to vital signs, } \\
\text { pressure } \\
\text { measurements, and } \\
\text { relative changes in } \\
\text { BF }_{\text {load and post- }} \\
\text { load periods. } \\
\text { Differences } \\
\text { between the sexes } \\
\text { with regard to vital } \\
\text { signs }\end{array}$ \\
\hline $\begin{array}{l}\text { Pearson`s } \\
\text { correlation } \\
\text { coefficient }\end{array}$ & $\begin{array}{l}\text { Continuous, } \\
\text { two } \\
\text { variables }\end{array}$ & $\begin{array}{l}\text { Age, BMI, } \\
\text { tissue } \\
\text { thickness, } \\
\text { compression, } \\
\text { contact area }\end{array}$ & & & $\begin{array}{l}\text { BMI, average } \\
\text { sacral tissue } \\
\text { pressure, peak } \\
\text { sacral pressure, and } \\
\text { sacral probe } \\
\text { pressure }\end{array}$ \\
\hline $\begin{array}{l}\text { Repeated } \\
\text { measures } \\
\text { ANOVA } \\
\text { (Pillai's trace): } \\
\text { Bonferroni test } \\
\text { or Games- } \\
\text { Howell test for } \\
\text { post-hoc } \\
\text { comparisons }\end{array}$ & $\begin{array}{l}\text { Continuous, } \\
\text { more than } \\
\text { two related } \\
\text { variables }\end{array}$ & & & $\begin{array}{l}\mathrm{BF}_{\text {load }} \text { with } \\
\text { regard to tissue } \\
\text { depths in the } \\
\text { study groups }\end{array}$ & $\begin{array}{l}\text { Differences } \\
\text { between the } \\
\text { mattresses with } \\
\text { regard to pressure } \\
\text { measurements and } \\
\text { between BF } \\
\text { responses during } \\
\text { the post-load } \\
\text { period with regard } \\
\text { to tissue depths }\end{array}$ \\
\hline
\end{tabular}

ANOVA: Analysis of variance, $\mathrm{BF}$ : blood flow, $\mathrm{BMI}$ : body mass index, $\mathrm{BF}_{\text {load }}$ : blood flow during load,

\section{Ethical considerations}

The studies were approved by the Regional Ethical Review Board (Dnr: M16606 and 03-523), and the studies were performed according to the World Medical Association Declaration of Helsinki (WMA, 2013). The studies were conducted in compliance with the Guidelines of International Conference on Harmonisation in Good Clinical Practice, ICH-GCP. The principles of autonomy, beneficence, non-maleficence, and justice for the participants were 
secured with following actions. Participation was grounded on oral and written informed consent. The registration of background variables was performed manually according to coded protocols. The digital images of ultrasound measurements were saved to the research database of the physiological clinic at the hospital. The coded list and protocol were kept separate and safe. The university was the responsible organization, the personal information was handled according to Swedish law (1998:204), and the participants were insured during participation.

The methods used in the two studies were non-invasive and were not associated with discomfort or pain. The PPG system was newly developed and was not considered a medical device because it did not have a medical purpose. Therefore, the device was not regulated by the laws of medical devices. However, a patient safety evaluation was performed by the department of medical devices and instrumentation at the hospital (MTÖ) where the patients were included to ensure that the device was safe to use in the studies.

Considerations were taken for patient safety when bringing the patients to a separate laboratory to participate in the studies. The medical approval from the responsible physician was obtained for the patient to leave the ward. The measurements were always done with two persons in the room, a registered nurse (the author) and an assistant nurse/registered nurse who was able to take actions in case of acute illness and to act according to basic hygiene regulations.

Participation in the studies had the potential to conflict with patient interests because participation included a 2.5 hour period away from the ward. Potential affected situations included training with a physiotherapist, clinical investigations and supervision, doctor appointments, drug administration, visits from relatives, and time for discharge. Therefore, the time for the measurement session was always selected in close contact with the ward staff, and they were always informed of the possibility to phone to end the session if something unplanned for the patient became scheduled. 



\section{RESULTS}

Vital signs for the participants in the different studies are presented in Table 4.

Table 4. Vital signs for the participants in the different studies.

\begin{tabular}{|c|c|c|c|c|c|c|c|c|}
\hline & \multirow{2}{*}{\multicolumn{2}{|c|}{$\begin{array}{l}\text { Studies I and II } \\
\text { healthy } \\
(\mathrm{n}=17)\end{array}$}} & \multicolumn{6}{|c|}{ Studies III and IV } \\
\hline & & & \multicolumn{2}{|c|}{$\begin{array}{l}\text { YOUNG healthy } \\
(\mathrm{n}=42)\end{array}$} & \multicolumn{2}{|c|}{$\begin{array}{l}\text { OLD healthy } \\
(\mathrm{n}=38)\end{array}$} & \multicolumn{2}{|c|}{$\begin{array}{l}\text { Patients } \\
(\mathrm{n}=35)\end{array}$} \\
\hline & Mean & SD & Mean & SD & Mean & SD & Mean & SD \\
\hline Age (years) & 68.5 & 7.1 & 41.7 & 12.9 & 75.4 & 7.8 & 79.8 & 7.9 \\
\hline BMI $\left(\mathrm{kg} / \mathrm{m}^{2}\right)$ & 25.2 & 2.6 & 24.4 & 3.8 & 25.2 & 3.4 & 26.6 & 4.9 \\
\hline Heart rate (bpm) & 66 & 7.4 & 64 & 9.3 & 68 & 9.8 & 72 & 8.1 \\
\hline $\mathrm{SBP}(\mathrm{mmHg})$ & 129.1 & 13.6 & 116.6 & 13.6 & 131.7 & 18.8 & 127.6 & 19.4 \\
\hline DBP $(\mathrm{mmHg})$ & 74.4 & 8.8 & 65.3 & 11.2 & 69.3 & 8.7 & 65.7 & 12.1 \\
\hline Body temperature $\left({ }^{\circ} \mathrm{C}\right)$ & 36.4 & 0.4 & 36.7 & 0.34 & 36.5 & 0.41 & 36.6 & 0.77 \\
\hline Skin temperature $\left({ }^{\circ} \mathrm{C}\right)$ & 32.3 & 1.8 & 34.4 & 1.2 & 34.2 & 1.0 & 33.8 & 1.3 \\
\hline
\end{tabular}

BMI: body mass index, SBP: systolic blood pressure, DBP: diastolic blood pressure, bpm: beats per minute

Four subjects in Studies I and II were on cardiac medications, including beta blockers $(n=3)$, calcium antagonists $(n=2)$, ACE inhibitor $(n=1)$, warfarin $(n=$ $1)$, and ASA ( $\mathrm{n}=1)$. In Studies III and IV, the most common cardiac medications were beta-blockers with 1 user in the YOUNG group, 11 users in the OLD group, and 21 users in the patient group. Agents acting on the renin-angiotensin system were the second most common with 8 users in the OLD group and 20 users in the patient group. These were followed by diuretic drugs with 1 user in the YOUNG group, 3 users in the OLD group, and 16 users in the patient group. Individuals with diabetes mellitus were found in Studies III and IV -2 in the OLD group and 12 in the patient group - and 9 of them were on diabetes medication. The mean value of the total RAPS score for the patients in Studies III and IV was $32.4 \pm 2.7$ points and varied from 23 points to 35 points. Ten patients had restricted ability to change position (score of 2 or 3 on the RAPS variable Mobility), and five patients were considered to be at risk for developing pressure ulcers.

\section{Tissue characterization}

Sacral tissue conditions were presented in Study I. The mean sacral tissue thickness (TTunload) was $26 \pm 13 \mathrm{~mm}$, and the thickness was significantly reduced 
to $10 \pm 5 \mathrm{~mm}$ while loading with the subject's own body weight (TTload) (p < 0.0005). The relative compression of the tissue while loading was $60.3 \pm 11.9 \%$, and the interface pressure reached values of at least $220 \mathrm{mmHg}$ in the sacral area. There were no differences between men and woman regarding tissue thickness, but there were strong correlations between BMI and TTunload $(r=0.68$, $\mathrm{p}=0.003)$ and $\mathrm{TT}_{\mathrm{load}}(\mathrm{r}=0.68, \mathrm{p}=0.003)$. No correlations were found between compression and any of the variables of age, BMI, TTunload, or TTload. In Study III, BMI, sacral probe pressure, average sacral pressure, and peak sacral pressure were tested for correlations while lying supine on a standard hospital mattress. There was a positive correlation between BMI and average sacral pressure $(r=$ $0.446, \mathrm{p}<0.01$ ) (Study IV).

\section{Variations in blood flow}

Studies II-IV showed large variations in blood flow with large standard deviations, and the data were not normally distributed (Tables 5 and 6).

Table 5. Relative change (\%) of blood flow (Study II) with median, mean, and standard deviation (SD).

\begin{tabular}{llllll} 
& & & & & \\
During load & median & 14.0 & 31.1 & 43.6 & 52.3 \\
$37.5 \mathrm{mmHg}$ & mean & 27.9 & 24.4 & 36.7 & 42.1 \\
& SD & 92.9 & 16.3 & 36.4 & 40.3 \\
After load & & & & & \\
O min & median & 13.8 & 2.3 & 10.1 & 0.0 \\
& mean & 90.7 & 16.1 & 16.7 & -1.2 \\
& SD & 220.2 & 35.1 & 31.3 & 26.6 \\
& & & & & \\
5 min & median & 11.3 & 2.6 & 5.1 & -3.4 \\
& mean & 15.0 & 3.6 & 2.5 & -6.0 \\
& SD & 38.6 & 12.3 & 10.1 & 23.6 \\
During load & median & -6.9 & 29.2 & 59.9 & 53.9 \\
50.0 mm $H g$ & mean & -3.9 & 32.6 & 74.9 & 53.3 \\
& SD & 71.9 & 20.4 & 86.1 & 75.8 \\
After load & & & & & \\
0 min & median & 57.4 & 9.0 & 15.4 & -0.2 \\
& mean & 224.2 & 22.9 & 63.2 & 4.23 \\
& SD & 631.0 & 46.7 & 114.2 & 36.7 \\
5 min & & & & & \\
& median & 18.9 & 5.5 & 3.2 & -3.6 \\
& mean & 294.1 & 8.1 & 5.2 & -4.0 \\
& SD & 1125.5 & 18.4 & 20.1 & 31.0 \\
\hline
\end{tabular}


Table 6. Relative change (\%) in blood flow (Study III) at different tissue depths while lying on a standard hospital mattress among healthy individuals $<65$ years ( $n=42$, YOUNG), healthy individuals $\geq 65$ years $(n=38, O L D)$, and patients $\geq 65$ years $(n=35)$.

\begin{tabular}{|c|c|c|c|c|c|c|c|c|c|c|}
\hline & \multicolumn{3}{|c|}{$1 \mathrm{~mm}$ depth } & \multicolumn{3}{|c|}{2 mm depth } & \multicolumn{3}{|c|}{$10 \mathrm{~mm}$ depth } \\
\hline & & median & mean & SD & median & mean & SD & median & mean & SD \\
\hline \multicolumn{11}{|c|}{ During load } \\
\hline & YOUNG & 28.6 & 34.8 & 46.4 & 20.8 & 30.6 & 48.6 & 10.7 & 18.0 & 70.6 \\
\hline & OLD & 22.9 & 23.1 & 36.9 & 31.9 & 45.1 & 63.2 & 20.6 & 18.8 & 53.2 \\
\hline & patients & 33.2 & 37.4 & 41.5 & 39.4 & 41.3 & 49.7 & 43.2 & 31.9 & 39.3 \\
\hline \multicolumn{11}{|c|}{ After load } \\
\hline 0 & YOUNG & 18.0 & 23.3 & 60.3 & -1.0 & -0.5 & 23.7 & 8.5 & 31.7 & 93.4 \\
\hline \multirow[t]{2}{*}{$\min$} & OLD & -3.0 & 6.0 & 51.3 & 4.1 & 18.1 & 72.5 & 15.9 & 33.4 & 117.9 \\
\hline & patients & 8.2 & 29.0 & 75.0 & 6.1 & 10.8 & 31.3 & -25.3 & -6.6 & 55.7 \\
\hline 1 & YOUNG & 5.4 & 8.0 & 33.5 & -0.12 & 2.6 & 28.9 & 18.2 & 37.6 & 77.9 \\
\hline \multirow[t]{2}{*}{$\min$} & OLD & 8.1 & 4.3 & 28.2 & -13.0 & 9.5 & 64.8 & 1.7 & 11.9 & 48.6 \\
\hline & patients & 0.3 & 14.8 & 68.8 & 11.3 & 13.0 & 25.5 & -11.9 & 1.8 & 57.4 \\
\hline 2 & YOUNG & 10.0 & 9.3 & 31.6 & 1.8 & 4.7 & 33.6 & 1.2 & 19.1 & 85.7 \\
\hline \multirow[t]{2}{*}{$\min$} & OLD & 10.4 & 6.4 & 21.4 & 8.1 & 24.5 & 61.9 & 6.0 & 24.8 & 77.3 \\
\hline & patients & 4.6 & 8.7 & 32.2 & 12.0 & 23.5 & 54.0 & 17.3 & 21.5 & 62.3 \\
\hline 5 & YOUNG & 10.9 & 12.8 & 33.6 & 7.3 & 5.5 & 26.2 & 5.3 & 27.5 & 82.5 \\
\hline \multirow[t]{2}{*}{$\min$} & OLD & 5.9 & 4.4 & 23.8 & 4.0 & 10.6 & 36.1 & 3.2 & 20.0 & 80.0 \\
\hline & patients & 2.9 & 2.7 & 23.9 & 10.1 & 14.7 & 28.1 & -12.3 & 7.4 & 50.6 \\
\hline 10 & YOUNG & 13.9 & 22.4 & 42.0 & 3.3 & 9.5 & 26.8 & 20.4 & 30.6 & 54.9 \\
\hline \multirow[t]{2}{*}{$\min$} & OLD & 5.9 & 3.5 & 22.2 & 4.5 & 8.6 & 43.0 & 4.0 & 9.0 & 46.2 \\
\hline & patients & 6.8 & 6.6 & 26.4 & 14.6 & 13.9 & 28.0 & -2.0 & 22.0 & 57.9 \\
\hline
\end{tabular}

There were no differences between the three study groups with regard to blood flow responses ( $\mathrm{BF}_{\text {load, }} \mathrm{BF}_{\text {overall, }} \mathrm{BF}_{\max }$ ) at any of the three measurement depths in Studies III and IV. There were also no differences between the groups with regard to the proportion of individuals with lack of PIV and individuals with hyperemic response during the post-load period. Therefore, the results of the blood flow response were presented as one group in Study IV.

In Study III, while lying supine on a standard hospital mattress, a hyperemic response after load could be seen in the subjects regardless of blood flow response during load. For those with an increase in BFload, many subjects in all three study groups had a hyperemic response $(82.8 \%-92.3 \%$ at $1 \mathrm{~mm}$ depth, $73.9 \%-81.5 \%$ at $2 \mathrm{~mm}$ depth, and $75.0-100.0 \%$ at $10 \mathrm{~mm}$ depth). 


\section{Pressure-induced vasodilation during load}

The pattern of blood flow responses that occurred most frequently in individuals exposed to $37.5 \mathrm{mmHg}$ and $50.0 \mathrm{mmHg}$ loads (Study II) was PIV, and this was referred to as "the standard appearance". The response was present in 10 of 17 individuals measured with PPG $(2 \mathrm{~mm}, 8 \mathrm{~mm}$, or $20 \mathrm{~mm}$ depths) and was higher at $50.0 \mathrm{mmHg}$ compared to $37.5 \mathrm{mmHg}$. At $1 \mathrm{~mm}$ depth measured with LDF, the variations were large and no pattern was discerned. Three individuals in Study II showed a decrease in blood flow (a lack of PIV) when measured with PPG during tissue pressure exposure, and 13 individuals showed such a response when measured with LDF. These responses were further explored in Studies III and IV.

While lying in a supine position on mattresses, a larger proportion of the subjects had a lack of PIV (Studies III and IV) at a tissue depth of $10 \mathrm{~mm}(35.1 \%-$ $56.9 \%$ ) compared to the more superficial tissue layers at tissue depths of $1 \mathrm{~mm}$ and $2 \mathrm{~mm}(20.0 \%-39.0 \%)$ (Table 7$)$. The results varied depending on the type of mattress.

Table 7. Proportions of subjects (n) with a lack of pressure-induced vasodilation (PIV) at different tissue depths and for different mattresses and the mean value of $B F_{\text {load }}(\%)$ on the different mattresses.

\begin{tabular}{lll|ll|ll}
\hline & \multicolumn{2}{l}{ 1 mm depth } & \multicolumn{2}{l}{ 2 mm depth } & \multicolumn{2}{c}{ 10 mm depth } \\
& $\mathrm{n}(\%)$ & Mean (SD) & $\mathrm{n}(\%)$ & Mean (SD) & $\mathrm{n}(\%)$ & Mean \\
\hline Non PIV & & & & & & \\
$\quad$ Standard & $23(21.3)$ & $-18.9(22.1)$ & $23(22.3)$ & $-24.7(18.6)$ & $41(39.8)$ & $-32.6(23.8)^{\mathrm{a}}$ \\
V-E foam/air & $27(24.8)$ & $-19.3(24.3)$ & $41(39.0)$ & $-21.2(14.2)$ & $58(56.9)$ & $-29.1(18.3)^{\mathrm{b}}$ \\
$\quad$ HRP foam & $34(30.6)$ & $-25.1(25.4)$ & $23(21.5)$ & $-34.5(17.4)$ & $41(39.0)$ & $-37.3(18.0)^{\mathrm{c}}$ \\
$\quad$ Alternating & $30(30.0)$ & $-19.8(23.0)$ & $20(20.0)$ & $-24.2(17.4)$ & $34(35.1)$ & $-33.2(19.3)^{\mathrm{d}}$ \\
\hline
\end{tabular}

Cochran Test (Q), McNemar Test with Bonferroni correction (level of significance $=0.0167$ ) for post-hoc comparison

a: $\mathrm{Q}(2)=22.6, \mathrm{p}<0.0005$, significance between $2 \mathrm{~mm} \& 10 \mathrm{~mm}$ depths

$\mathrm{b}: \mathrm{Q}(2)=11.0, \mathrm{p}=0.004$, significance between $1 \mathrm{~mm} \& 10 \mathrm{~mm}$ depths

c: $\mathrm{Q}(2)=8.7, \mathrm{p}=0.013$, significance between $2 \mathrm{~mm} \& 10 \mathrm{~mm}$ depths

$\mathrm{d}: \mathrm{Q}(2)=9.2, \mathrm{p}=0.010$, significance between $2 \mathrm{~mm} \& 10 \mathrm{~mm}$ depths

\section{The mattresses}

In Study IV, a greater proportion of subjects had a lack of PIV on the V-E foam/air mattress compared to the alternating mattress at tissue depths of $2 \mathrm{~mm}$ $(39.0 \%$ vs. $20.0 \%$, respectively, $\mathrm{p}=0.002)$ and $10 \mathrm{~mm}(56.9 \%$ vs. $35.1 \%$, respectively, $\mathrm{p}=0.020$ ) (Table 7). 


\section{Blood flow during the post-load period}

Fourteen individuals showed RH according to LDF measurements, and four individuals showed RH according to PPG measurements (Study II). In Study III, $44.4 \%-75.0 \%$ of the YOUNG group, $50.0 \%-71.4 \%$ of the OLD group, and $40.0 \%-85.7 \%$ of the patients had RH responses at different tissue depths.

There were differences between the measurement depths (Studies III and IV) with regard to the blood flow responses during the post-load period (Table 8). The BFoverall response was significantly larger at the deeper tissue depth of 10 $\mathrm{mm}$ compared to the superficial tissue depths of $1 \mathrm{~mm}$ and $2 \mathrm{~mm}$. Similarly, the $\mathrm{BF}_{\max }$ was higher at the deeper tissue depth compared with the superficial tissue depths. Timemax did not differ between the measurement depths.

Table 8. The relative change from the related baseline in overall blood flow (BF overall $)(\%)$, the maximum blood flow $\left(B F_{\max }\right)(\%)$, and when BFmax occurred (Time $\max$ ) (min) at different measurement depths during the post-load period on the different mattresses. N.S. = not significant.

\begin{tabular}{llllllll|l}
\hline & & 1 mm depth & \multicolumn{2}{c}{ 2 mm depth } & \multicolumn{2}{c}{ 10 mm depth } & \\
& & mean & SD & mean & SD & mean & SD & p-value \\
\hline BF $_{\text {overall }}$ & Standard & 236.7 & 185.6 & 274.5 & 222.1 & 472.8 & 413.3 & $<0.0005$ \\
& V-E foam/air & 220.4 & 214.3 & 307.9 & 341.3 & 446.9 & 510.4 & 0.002 \\
& HRP foam & 233.8 & 224.7 & 276.9 & 258.5 & 460.4 & 516.5 & 0.002 \\
& Alternating & 261.0 & 639.3 & 219.4 & 141.3 & 584.6 & 857.4 & 0.041 \\
& & & & & & & & \\
$\mathrm{BF}_{\max }$ & Standard & 41.4 & 60.2 & 35.8 & 58.0 & 69.2 & 98.5 & 0.015 \\
& V-E foam/air & 32.3 & 74.3 & 40.6 & 60.3 & 52.7 & 98.1 & N.S \\
& HRP foam & 30.1 & 56.4 & 36.6 & 72.1 & 68.6 & 100.0 & 0.002 \\
& Alternating & 43.7 & 125.9 & 23.5 & 34.3 & 81.2 & 181.3 & N.S \\
& & & & & & & & \\
Time $_{\max }$ & Standard & 4.4 & 4.1 & 4.0 & 3.9 & 3.5 & 3.6 & N.S \\
& V-E foam/air & 5.2 & 4.2 & 4.7 & 3.9 & 4.7 & 3.8 & N.S \\
& HRP foam & 4.0 & 4.1 & 3.6 & 3.4 & 4.2 & 3.9 & N.S \\
& Alternating & 3.5 & 3.9 & 3.8 & 3.7 & 4.0 & 3.9 & N.S \\
\hline
\end{tabular}

In Study III, the linear mixed model analysis (model 1) confirmed that there were differences in $\mathrm{BF}_{\text {overall }}$ between the study groups $(\mathrm{p}=0.048)$ and between the $1 \mathrm{~mm}$ and $10 \mathrm{~mm}$ measurement depths ( $\mathrm{p}$ 0.0005), with higher response at $10 \mathrm{~mm}$ tissue depth. The model was adjusted for sacral probe pressure, BFload, and age. When compared to $\mathrm{BF}_{\max }$, differences were only seen between the 1 $\mathrm{mm}$ and $10 \mathrm{~mm}$ measurement depths ( $\mathrm{p}$ 0.0005), with higher response at 10 $\mathrm{mm}$ tissue depth, in the mixed model analysis (model 2) when adjusting for pulse, BFload, and number of medications. Medications were tested as confounding variables in the final models (models 1 and 2), but there was no interaction with the separate substances or when grouping them into cardiac and diabetic drugs. 
In Study III, Timemax showed large variations while the subjects were lying on a standard mattress. $\mathrm{BF}_{\max }$ occurred within the first minute in $37.5 \%-50.0 \%$ of the YOUNG group, $29.7 \%-47.2 \%$ of the OLD group, and $26.7 \%-39.4 \%$ of the patients depending on the measurement depth. Furthermore, $11.1 \%-35.1 \%$ of the subjects experienced $\mathrm{BF}_{\max }$ at the end of the 10 minute measurement period depending on measurement depths and study groups.

\section{The mattresses}

No significant differences were found between the mattresses with regard to $\mathrm{BF}_{\text {overall, }} \mathrm{BF}_{\max }$, or Timemax (Study IV).

\section{The high-risk blood flow response}

Twenty-nine subjects with a lack of both PIV and RH (in some or all tissue depths) - the high-risk blood flow response - were identified in Study III, including 11 subjects in the YOUNG group, 9 subjects in the OLD group (two of which had diabetes), and 9 subjects in the patient group. All of the patients with the high-risk blood flow response had cardiac diagnoses, six had irregular heart rhythms, five had diabetes, and three patients had had a stroke. The subjects with the high-risk response had a larger number of medications (5.1 \pm 6.8 medications) than the subjects without the high-risk response $(3.05 \pm 4.0$ medications) $(p=0.031)$. Only one patient was identified as at risk according to their total RAPS score.

In Study IV, three YOUNG individuals, three OLD individuals, and five patients were identified with a lack of PIV and RH that indicated a high-risk blood flow response on three or four of the mattresses. All of the individuals with high-risk blood flow response $(\mathrm{n}=6)$ in the two healthy populations had a low BMI ranging from $20.2 \mathrm{~kg} / \mathrm{m}^{2}$ to $21.9 \mathrm{~kg} / \mathrm{m}^{2}$ (except for one subject with a BMI of $30.1 \mathrm{~kg} / \mathrm{m}^{2}$ ), and all were women. Among the patients with the high-risk blood flow response (three men and two women), the BMI ranged from 18.7 $\mathrm{kg} / \mathrm{m}^{2}$ to $28.7 \mathrm{~kg} / \mathrm{m}^{2}$. None of them were identified as being at risk for developing pressure ulcers according to their RAPS score. In addition, 23 individuals had occasional high-risk blood flow responses on two of the mattresses. 


\section{Pressure}

In Study IV, there was a positive correlation between average sacral pressure and peak sacral pressure $(\mathrm{r}=0.370, \mathrm{p}<0.01)$ while lying supine on a standard hospital mattress. The mean sacral pressure in Study III was the lowest in the YOUNG group $(26.0 \pm 2.1 \mathrm{mmHg})$ and the highest in the patients $(28.8 \pm 2.1$ $\mathrm{mmHg}$ ), and significant differences were seen between all three groups. The peak sacral pressure differed in a similar manner (Table 9).

Table 9. Pressure measurements in Studies III and IV during load in the YOUNG group, the OLD group, and the patients. All values are in $\mathrm{mmHg}$.

\begin{tabular}{|c|c|c|c|c|c|c|c|c|}
\hline & & $\begin{array}{l}\text { Standard } \\
\text { mattress }\end{array}$ & & $\begin{array}{l}\text { E foam/air } \\
\text { mattress }\end{array}$ & & $\begin{array}{c}\text { HRP foam } \\
\text { mattress }\end{array}$ & & $\begin{array}{l}\text { Iternating } \\
\text { mattress }\end{array}$ \\
\hline & $\mathrm{n}$ & Mean (SD) & $\mathrm{n}$ & Mean (SD) & $\mathrm{n}$ & Mean (SD) & $\mathrm{n}$ & Mean (SD) \\
\hline Average sacral pressure & & $27.4(2.8)$ & & $23.5(2.5)$ & & $25.6(2.3)$ & & \\
\hline YOUNG & 42 & $26.0(2.1)$ & 42 & $22.1(2.0)$ & 42 & $24.5(1.5)$ & & \\
\hline OLD & 38 & $27.6(2.5)$ & 38 & $23.8(2.3)$ & 38 & $25.6(2.1)$ & & \\
\hline Patients & 34 & $28.8(2.1)$ & 34 & $24.9(2.3)$ & 34 & $27.2(2.5)$ & & \\
\hline Peak sacral pressure & & $64.1(26.5)$ & & $49.3(11.1)$ & & $59.5(18.0)$ & & \\
\hline YOUNG & 42 & $57.3(17.2)$ & 42 & $49.0(14.2)$ & 42 & $51.3(11.1)$ & & \\
\hline OLD & 38 & $60.0(15.6)$ & 38 & $46.6(4.5)$ & 38 & $57.6(14.7)$. & & \\
\hline Patients & 34 & $76.8(38.7)$ & 33 & $52.8(11.3)$ & 34 & $70.3(24.1)$ & & \\
\hline Sacral probe pressure & & $34.8(14.1)$ & & $29.2(14.0)$ & & $33.1(14.7)$ & & $39.1(16.7)$ \\
\hline YOUNG & 35 & $34.8(14.4)$ & 36 & $29.3(10.1)$ & 36 & $34.3(12.2)$ & 31 & $38.5(8.5)$ \\
\hline OLD & 32 & $29.7(10.0)$ & 31 & $24.7(10.6)$ & 32 & $28.5(8.1)$ & 30 & $37.1(12.1)$ \\
\hline Patients & 29 & $40.5(15.3)$ & 28 & 34.4 (19.7) & 29 & $34.6(20.1)$ & 28 & $41.5(26.0)$ \\
\hline
\end{tabular}

\section{The mattresses}

There were similar differences between the groups on the different mattresses in Study IV (Table 9). There were significant differences between the three foam mattresses with regard to average sacral pressure and peak sacral pressure. The V-E foam/air mattress had a significantly lower local probe pressure value than the other three mattresses $(p<0.0005)$. 



\section{DISCUSSION}

\section{Variations in blood flow}

\section{Perspectives on microcirculation and pressure ulcer etiology}

In Study I, the perspective of the microcirculation and the blood flow responses was from the traditional view of microcirculation and its role in pressure ulcer etiology. This view sees the microcirculation as providing a transport function to supply the cells with oxygen and to remove toxic metabolites in the area around the cells (Jiang et al., 2011, Kosiak, 1961). Pressure on the skin surface can lead to compression of these blood vessels or, in the worst case, a total collapse of the vessel. Thus pressure on the skin should be reflected as a decrease in blood flow or, in the case of a total collapse, a lack of blood flow altogether. As a result of ischemic occlusion, $\mathrm{RH}$ is expected to develop as a way to maximize the transport of oxygenated blood and to rapidly remove accumulated metabolites.

The results in Study I were presented as the presence or absence of blood flow, and Study II involved assessment of RH. This was in line with several earlier studies on blood flow that reported a decrease or occlusion in blood flow and subsequent RH in high-risk populations such as geriatric patients (Bennett et al., 1981), stroke patients (Schubert and Héraud, 1994), and patients with hemiplegia (Ek et al., 1987) compared to healthy or non-risk individuals.

While exploring the tissue blood flow during pressure exposures of 37.5 $\mathrm{mmHg}$ and $50.00 \mathrm{mmHg}$ in Study II, large variations in blood flow with large standard deviations were seen. However, the reported standard response of blood flow was, somewhat surprisingly, an increase in blood flow. Nevertheless, the results of the earlier studies showed an increase of blood flow in many situations, but these findings were not commented on in those studies (Bennett et al., 1981, Ek et al., 1987, Schubert and Héraud, 1994). Schubert and Fagrell reported in an experimental study that the sacral skin blood flow increased in healthy individuals in response to pressures up to $12-50 \mathrm{mmHg}$, but they explained these findings as related to temperature increases or to nonlinear pressure distribution that caused a redistribution of blood flow (Schubert 
and Fagrell, 1989). Some evidence in the literature supports the findings in Study II. Sanada et al showed that the patients who developed pressure ulcers after long surgeries were the same ones who had no increase in blood flow during the surgery (Sanada et al., 1997). Xakellis et al showed that healthy subjects of different ages lying on a mattress and exposed to pressures less than $32 \mathrm{mmHg}$ demonstrated a significant increase in dermal blood flow (Xakellis et al., 1993). They speculated that the origin of this "unexpected increase" was a vasodilatory reflex in response to the vessels being partially occluded. Herrman et al showed an initial increase with low levels of pressure exposure and suggested that this was due to vasodilation in response to increased skin surface pressure as a result of a decrease in transmural pressure on the arterioles (Herrman et al., 1999). All the studies mentioned above described the phenomenon of PIV but did not relate it to a solid concept. Such work was performed by Fromy and Abraham in the late 1990s and now the concept of PIV is well developed and many of the basic mechanisms have been explored and related to pressure ulcer etiology (Abraham et al., 2001, Fromy et al., 1998, Fromy et al., 2012, Fromy et al., 2000, Roustit and Cracowski, 2013).

The results in Study II, as supported by the literature of PIV, led to the aims of Studies III and IV to explore and characterize PIV and RH at different depths and in different populations and to determine the possibility of using such phenomena to evaluate pressure-redistribution support surfaces. The results from Studies III and IV showed that blood flow responses, including PIV and $\mathrm{RH}$, differed between tissue depths and that some persons had depressed vasodilation during and/or after tissue exposure to pressure. These responses also differed between different pressure-redistribution support surfaces, but these differences only have limited potential for use in evaluating these products.

The pressure ulcer research field has not yet adapted to the concept of PIV and to the different perspective of the circulation as having an important function in regulating the blood flow to protect the tissue that is exposed to pressure. Current work, however, has begun develop a new framework of key components in pressure ulcer etiology and their relation to tissue damage, and a report on a "new pressure ulcer conceptual framework" has recently been published (Coleman et al., 2014). This work still describes circulation in terms of transport, but it recognizes the individual's vascular physiological function but relates it primarily to diabetes and low albumin. However, they emphasized that it is difficult to ascertain the most crucial factors relating to perfusion and stated that further in-depth research is needed. This thesis is a response to that appeal by contributing to the understanding of the mechanisms that are 
important to pressure ulcer development and by bringing a perspective of blood flow regulation and endothelial function that is anchored in clinical relevant studies. This perspective fits naturally within the new pressure ulcer conceptual framework as a part of the susceptibility and tolerance of the individual and adds a new dimension of a regulatory function for perfusion.

\section{Characterization of PIV}

This thesis has defined PIV as an increase in blood flow during pressure exposure to pressure compared to baseline. This is not strictly according to the concept of PIV developed by Fromy and colleagues. They explored the phenomenon through experimental setups that monitored blood flow during continuous pressure increases, and they described the PIV response as a slowly adapting response. While the pressure increase was ongoing, the blood flow decreased after an initial increase. However, when the pressure increase was stopped and the pressure held at a stable level the blood flow adjusted and an increase in blood flow, usually greater than baseline, occurred (Abraham et al., 2001). Thus it was shown to be possible to have an increase in blood flow after a pressure increase, but due to influences of a high pressure level that counteracted the PIV response the blood flow did not increase over baseline. However, the authors considered this to be PIV development in this situation despite the impaired blood flow. Due to the design of Studies III and IV in which we tried to mimic a clinical situation as closely as possible, it was not possible to monitor the pressure increase that occurred immediately after the participants assumed a supine position on the bed. The assessment of blood flow during pressure exposure was done at the end of the 10 minute period at which time the PIV response was fully developed.

It is possible that some of the occasions that were assessed as "lack of PIV", i.e. a decrease in blood flow, had an element of PIV but were so affected by the pressure level that PIV was heavily depressed below baseline. One might argue that it is more correct to refer to this as "depressed PIV" instead, which would be consistent with the strict definition of PIV. However, if a pressure level of 26$29 \mathrm{mmHg}$ (the average sacral pressure in Study III) results in a decrease in blood flow, one could speculate that the PIV response is abnormal. This also points to the fact that PIV is defined to be a pressure-induced vasodilation due to nonnoxious pressure. When blood flow is above baseline levels, it is obvious that the pressure is non-noxious but the question is at which point does the pressure becomes noxious. The findings of Sanada et al that persons without the ability 
to increase blood flow during tissue exposure to pressure during long surgeries were the ones who developed pressure ulcers during the recovery period after the surgery supports the chosen threshold at baseline levels in this thesis (Sanada et al., 1997).

As shown in this thesis, similar pressure magnitudes can give different vascular responses in different individuals. It was demonstrated that a pressure of at least $120 \mathrm{mmHg}$ is required for blood flow cessation in healthy seated individuals while $20-30 \mathrm{mmHg}$ is sometimes enough to generate the same response in geriatric hospital patients (Bennett et al., 1981). The experimental studies of Fromy and colleagues on PIV explored the response by applying progressively greater pressures (Abraham et al., 2001, Garry et al., 2005, Gaubert et al., 2007), and in young individuals the maximal PIV response in the finger was seen at $31.5 \pm 2.3 \mathrm{mmHg}$ (at a rate of pressure increase of $0.08 \mathrm{mmHg} / \mathrm{s}$ ) (Fromy et al., 2010) and at $37.5 \pm 20 \mathrm{mmHg}$ (at a rate of pressure increase of 5 $\mathrm{mmHg} / \mathrm{s}$ ) (Fromy et al., 1998). Studies of the sacral tissue in healthy individuals showed a maximal PIV response at $25-50 \mathrm{mmHg}$ with a further decrease in blood flow at greater pressure levels (Schubert and Fagrell, 1989). They also studied sacral tissue blood flow during pressure exposure in a supine position, which was similar to Studies III and IV, and showed that PIV was present under pressures of $26.8 \pm 3.0 \mathrm{mmHg}$ in orthopedic trauma patients and a decrease in blood flow in patients with spinal cord injuries exposed to pressures of $23.7 \pm$ $4.9 \mathrm{mmHg}$ (Sae-Sia et al., 2007). They also stated that the pressure magnitude in the groups were high enough to cause RH in some cases. In line with these findings, Noble et al showed that applying pressure with $2.5 \mathrm{~kg}$ weights to the sacrum resulted in a reduction of blood flow in smokers and non-smokers. They also showed that RH occurred after pressure release, but the level of RH was reduced in the smokers (Noble et al., 2003).

\section{Evaluation of support surfaces}

Studies II-IV showed large blood flow variations, and this is probably the explanation for why there was no differences in blood flow between study groups and mattresses in terms of means and standard deviations and why a relationship between blood flow and pressure was not established. Despite clear differences in pressure between different populations (Study III) and different mattresses (Study IV), no differences were seen in blood flow between the groups. Some previous studies found the same difficulties while trying to relate 
blood flow to interface pressure on different support surfaces (Goossens and Rithalia, 2008, Sonenblum et al., 2014). For example, Sonenblum et al. found differences in pressure between different seat cushions but no differences in blood flow measured with LDF. They also found large variations between subjects and higher pressure magnitudes while sitting (Sonenblum et al., 2014). Goossens and Rithalia on the other hand, found no differences in interface pressure between three mattresses, but they did find differences in blood flow using LDF and drew the same conclusion as this thesis that maximal interface pressure has no relation to blood flow in human tissue (Goossens and Rithalia, 2008).

Study II showed different patterns of blood flow responses during and after pressure exposure at an individual level, and focusing on the individual PIV and $\mathrm{RH}$ responses in Studies III and IV was an accessible way to explore differences in blood flow on different pressure-redistributing surfaces. The differences in the proportions of individuals with these responses could be discerned in different populations and on different support surfaces. It is interesting that the V-E foam/air mattress - which had the lowest pressure values - had a greater proportion of subjects lacking PIV in the deeper tissue structures compared to both the other foam mattresses and to the alternating pressure mattress. The implication is that the microcirculation was most affected in deeper tissues on the V-E foam/air mattress, and this might mean that the pressure levels had become noxious in these situations. The cause of this was not revealed, but one can speculate that the V-E foam/air mattress had caused higher internal strain and stress that led to more deformed tissues that affected the microcirculation throughout the entire tissue structures. As discussed in Study III, studies using magnetic resonance imaging and mathematical modeling have shown that high strain and stress can be found at various depths in tissue exposed to pressure and that these forces are not uniform (Linder-Ganz et al., 2007, Oomens et al., 2003). The applied pressure might become harmful in these areas and affect the microcirculation. In relation to different support surfaces, it was shown that despite a high reduction in the interface pressure, the deformation in deeper tissues was high enough to be a risk for damage in the tissue (Oomens et al., 2003).

In summary, the results in this thesis showed that the evaluation of pressure-redistribution support surfaces in terms of mean blood flow during and after tissue exposure is not feasible. Although the PIV response differed between different mattresses, it is difficult to see that it would be a possible way to evaluate different support surfaces because the PIV response is strongly linked to the regulatory aspects and endothelial function in the individual. On 
the other hand, assessment of PIV and RH could be a new possibility to assess individualized physiological measurements of mechanisms known to be related to pressure ulcer development. The current use of risk assessment tools such as pressure ulcer risk assessment scales monitor variables that reflect changes in physiology and biomechanics but do not measure the impact directly. The RAPS scale used in this thesis includes the variable friction/shear, but this is a variable that is not possible to measure quantitatively in clinical practice. It has been shown that nurses have difficulties when performing risk assessments to quantify shear, or even recognizing it in the first place, and the higher damage effect when combining pressure and shear, and that difficulties tend to lead to an underestimation of the variable (Tescher et al., 2012). This could be one explanation for why only one patient who was at-risk according to RAPS had a microcirculatory high-risk response, i.e. lack of PIV and RH, in this thesis.

Furthermore, if a relationship could be established between a lack of PIV and high strain, stress, and deformation in the deeper tissue structures, this could be a way of monitor variables that reflect changes in both physiology and biomechanical components in tissue exposed to pressure. This novel approach to assessing PIV and RH might have the potential to improve the ability to identify patients at high-risk of pressure ulcer development and to be a complement to the risk assessment tools currently in use.

\section{The development and evaluation of the probe}

\section{Measurement depths}

Study I showed that the tissue thickness in the sacral area was about $1-3 \mathrm{~cm}$ in healthy individuals, and that the tissue volume was highly compressed by about $60 \%$ when lying on a hard surface. During this type of tissue exposure, the tissue thickness was about $0.5-1.5 \mathrm{~cm}$. On the basis of this result, the measurements depths were modified in the elaborated probe used in Studies III and IV to focus on depths of $1 \mathrm{~mm}, 2 \mathrm{~mm}$, and $10 \mathrm{~mm}$. The deepest measurement depth of $20 \mathrm{~mm}$ in Study I was not utilized because this blood flow signal not only included information from the sacral cutaneous tissue, but also presumably included bone and deeper tissue structures. It has previously been shown that it is possible to detect a signal originating in the bone using PPG (Naslund et al., 2006). However, Study I included measurement depths at $8 \mathrm{~mm}$ despite six of the participants having less tissue thickness than that, and this 
likely influenced the results in the same way as the measurement depth of 20 $\mathrm{mm}$. This is similar to Study II that utilized measurements at $20 \mathrm{~mm}$ but included five participants who had less than $20 \mathrm{~mm}$ sacral tissue thickness. Due to these limitations, the results of Studies I and II cannot be used to support any of the, in the literature, presented theories about the tissue depth at which ulceration begins.

The combined use of LDF and PPG makes it possible to measure blood flow at different depths in the tissue, but it is essential to be able to discriminate between the different depths. The depth of measurement using the LDF technique depends on the wavelength and fiber separation used. In Studies I and II, a He-Ne laser was used with a wavelength of $632.8 \mathrm{~nm}$, and Monte Carlo simulations using a He-Ne laser show a measurement depth of $0.20-0.24 \mathrm{~mm}$ depending on the blood content (Wardell et al., 1993). In Studies III and IV, a solid-state diode laser was used with a wavelength of $780 \mathrm{~nm}$, and Monte Carlo simulations show a measurement depth of $0.255-0.96 \mathrm{~mm}$ in muscle depending on the fiber separation (Fredriksson et al., 2009).

Studies using a similar modality of the PPG technique as in this present study have explored blood flow changes in patellar bone (Naslund et al., 2006) and in the tibial anterior and trapezius muscles (Sandberg et al., 2005, Zhang et al., 2001). These studies were able to discriminate between superficial blood flow using a wavelength of $560 \mathrm{~nm}$ and a source-to-detector distance of $3.5 \mathrm{~mm}$, and they could measure muscle blood flow using a wavelength of $806 \mathrm{~nm}$ or $880 \mathrm{~nm}$ with a source-to-detector distance of $10 \mathrm{~mm}, 20 \mathrm{~mm}$, or $25 \mathrm{~mm}$. In a validation of the measurement depths of the PPG prototype probe used in Studies I and II, measurements depths of $<4 \mathrm{~mm}, 10-15 \mathrm{~mm}$, and $>23 \mathrm{~mm}$ could be discriminated based on the different wave-lengths and source-to-detector separations that were used (Hagblad et al., 2010). As a consensus from these experimental studies one may assume that pulsatile blood flow variations can be monitored from approximate depths of $2 \mathrm{~mm}$ using $560 \mathrm{~nm}$ light, depths of $8-10 \mathrm{~mm}$ using $810 \mathrm{~nm}$ light (source-to-detector separation $=10 \mathrm{~mm}$ ), and a depth of $20 \mathrm{~mm}$ using $806 \mathrm{~nm}$ or $880 \mathrm{~nm}$ light (source-to-detector separation = $10 \mathrm{~mm})$.

\section{Considerations of the optical techniques}

It has previously been shown that tissue compression affects the PPG signal, but to what extent is unknown (Allen, 2007). Compared to unloaded tissue, the light from the PPG device penetrates more deeply into the compressed tissue to a 
certain depth. The compressed tissue tends to be more compact and has a larger blood volume, and this leads to an increase in the PPG signal. In Study I, the tissue was shown to be highly compressed and in such cases, the potential contribution of the increased blood flow signal can lead to an underestimation of the number of cases in which PIV is absent. However, the decrease in blood flow is of the greatest importance in this thesis, and in cases where a decrease in blood flow is detected this decrease is most certainly of physiological origin even if the true value might be even lower if not for the contribution from compression. One may speculate if there is a similar contribution due to compression in the LDF signal, but Fromy et al have shown that PIV can be blocked by drugs locally injected in the tissue (Fromy et al., 2000) or by iontophores (Garry et al., 2005). If the signal had a contribution due to compression, the blood flow signal monitored in these studies still would have shown an increase. These experiments should be repeated with the use of PPG in a similar setup to provide knowledge of the relative contribution of compression when using the PPG technique.

The differences in blood flow responses at the superficial depths measured with LDF and green-light PPG might be influenced by the methodological differences between the two optical techniques. LDF is a single-point measurement in a very small volume of tissue (Jakobsson and Nilsson, 1993), but the PPG system measures the mean value in a larger volume (Sandberg et al., 2005). PPG might be more relevant in clinical applications due to its larger measurement volume, but LDF provides the opportunity to compare the results with previous findings due to its status as the gold standard for microcirculatory assessments (Liao et al., 2013). However, differences remained when comparing green-light PPG to IR-light PPG, and this supports the assumption that the differences in responses are due to functional differences between superficial and deeper vascular beds.

\section{Influences of the prototype probe}

The blood flow at the most superficial measurements using LDF was highly affected by pressure exposure in Studies I and II. Studies III and IV showed that a larger proportion of subjects had a lack of PIV at a tissue depth of $10 \mathrm{~mm}$ compared to the superficial tissue layers at depths of $1 \mathrm{~mm}$ and $2 \mathrm{~mm}$, which was contradictory to the findings in Studies I and II. However, there were differences in methodology between the studies using two different optical probes. The system used in Studies I and II was a stiff prototype probe that 
restricted measurements to the prone position while loading with relevant pressure values ( $37.5 \mathrm{mmHg}$ and $50 \mathrm{mmHg}$ ). The design, with its relatively sharpened edges, might have influenced the results - especially measurements of the superficial blood flow - by creating tissue stress in that area. Furthermore, only three individuals in the previous studies had decreased blood flow at deeper tissue depths, which is a very small number to draw conclusions from. While lying in the supine position, the prototype restricted measurements to being taken on a stiff test bench, and this led to very high pressure values of at least $220 \mathrm{mmHg}$. These are extreme pressure levels well above the threshold for harmful pressure levels (Linder-Ganz et al., 2006). However, the development of the prototype probe at the prospect of Studies III and IV into a thin flexible probe with the ability to measure a larger area and handle larger variations in signal strength solved the problems that were present in Studies I and II.

\section{Methodological considerations}

\section{Design and samples}

Studies I and II were experimental in nature and focused on the ability to discriminate blood flow responses at different depths and to identify mechanisms relevant to pressure ulcer etiology using a new prototype set-up. Therefore, the studies had a number of limitations due to the undeveloped probe design, but the results of the studies had enough substance to support a further elaboration of the probe and the performance of explorative studies in clinical settings.

While collecting data in Studies III and IV, we gained insights into the demands of the study design on the most immobile and vulnerable patients who were not able to participate. All included patients were able to engage in active transfers between experiments, but 10 patients had restricted ability to change position and had a score of 2 or 3 on the RAPS Mobility variable. None of the patients were in need of scheduled turning regimens, and only five patients were considered to be at risk for pressure ulcer development according to their total RAPS score. Because we were unable to include the most vulnerable patients, further investigations of pressure-induced blood flow responses such as PIV and RH in high-risk populations are needed.

The aim of this thesis was to reveal the vascular mechanisms relevant in pressure ulcer etiology. RH is widely accepted to be involved in blood flow 
responses to occlusive pressure exposure. This phenomenon was described earlier in this thesis, and the results of Studies II-IV imply that RH is present in different tissue structures. As for PIV, this thesis has shown that the phenomenon is applicable in clinically relevant conditions and that it can also be present in different tissue structures. Because the concept of measuring both $\mathrm{RH}$ and PIV as a means of detecting a "high-risk response" is still new, future studies are needed to determine if this is an appropriate approach.

All studies in this thesis had a cross-sectional design, and the limitation of such a design is that it cannot explore day-to-day variability in the blood flow responses in the individuals (Polit and Beck, 2007). It would be interesting to see if the individuals with the high-risk blood flow responses had the same response over time, especially the individuals in the healthy group who had no obvious reason for regulatory dysfunction. In addition, only one body site was explored in this thesis, the sacral area. This was chosen because it is an area at high risk for ulceration - together with the heels (Baath et al., 2014) - and because it is relatively easy to perform blood flow measurements in this area. It would be interesting to examine the blood flow responses at different body sights that are prone to pressure ulcer development as well as sites that are not prone to ulcers to see if there is a difference between them. PIV has previously been examined in the fingers (Abraham et al., 2001, Fromy et al., 2012) and in the upper part of the foot in diabetics (Koitka et al., 2004). These sites have higher perfusion than the sacrum - which is a low perfused area with the branches of the vessel tree coming from the sides - and no large vessels are present (Tortora and Derrickson, 2011). As found in Studies III and IV, it is demanding to perform blood flow measurements in the sacrum of totally immobile persons, and it would, therefore, be advantageous to explore PIV and $\mathrm{RH}$ in more easily accessible body sites. Thus, other measurements and probe designs need to be developed. Because both the LDF and PPG technique have limitations in terms of repeatability where the variability relates to site recording and variances in day-to-day measurements (Allen, 2007, Wright et al., 2006), some considerations are needed on how to perform long-term studies or clinical trials with interventions. 


\section{Data analysis}

The analysis of the material in Studies III and IV in terms of the proportion of subjects with a lack of PIV might have some limitations. In Study III, the most common response in the subjects was a lack of PIV at only one measurement depth, although some of the individuals had a lack of PIV at all tissue depths. Looking at the individual level, this result indicates that the endothelial function and response to pressure is not homogenous in the tissue volume, but the cause of this is not known. In Study IV, the individuals identified with the "high-risk response" were the one who had the "high-risk response" on three or on all four of the mattresses. In the cases of non-risk on the fourth mattress, the blood flow was analyzed in-depth and found to be heavily depressed and the relative change was just above zero. To summarize, the total lack of PIV seen in highrisk populations in previous experimental studies in the most superficial skin (Fromy et al., 2010, Koitka et al., 2004) was not found to be completely transferrable to clinically relevant conditions and in different tissue structures because the lack of PIV in our studies was heterogeneous among individuals and tissue depths.

The study design provided a large amount of data. To restrict it to some extent, only certain periods of blood flow were extracted; seven measurement periods in 115 subjects at three different depths to give a potential 2,415 blood flow measurement occasions in Study III. When added four different mattresses in Study IV, the number of potential blood flow measurement occasions expanded to 9,660 occasions. This large amount of data allowed for statistical analysis to be performed. The missing data were mainly due to low quality of the signal because the subject moved or was not in the right position during the measurement. In some cases, the subject chose to end the session before all measurements had been taken. The imputation of missing data was done as conservatively as possible. The relative change of blood flow was of interest, and the imputation used no change in blood flow when performed for the first or last time point, and it used the mean value of the previous and following value if it was performed at other time points. This will most likely lead to an underestimation of relative change and will not overestimate the results in any way. Finally, imputation was made only for isolated values, and if more than one missing value followed each other, then no imputation was made. The imputation magnitude of $2.7 \%$ is considered low in statistical terms. 


\section{Generalizability}

Many of the individuals in the healthy groups - and all of the patients - were on various medications when the measurements in the different studies were made. The patients in Studies III and IV were taking larger numbers of medications compared to the healthy groups, and these medications have the potential to affect the microcirculation in different ways. The results showed that the number of medications influenced $\mathrm{BF}$ max, and this might indicate that the number of medications is reflective of the individual's general state of health. The study design in Studies III and IV was chosen to mirror the clinical situation by comparing inpatients with a population as close as possible to a normal population, and the selection of the healthy individuals fulfilled this criterion. Therefore, the microcirculatory status of the healthy group is considered to be generalizable to the wider population. The healthy group might be on medications to various degrees, but the general health status of these individuals is not seriously affected by any of the medical disorders they might have, and all of these subjects described themselves as healthy. The selection of inpatients included almost any available patients in the three medical specialist departments of the hospital. Only a few patients from the surgical ward were included and these had not yet undergone surgery. The patients included in the study are, therefore, considered to be representative of the general population of elderly inpatients in different medical hospital wards.

\section{Clinical perspectives}

Assessment, treatment, and evaluation of pressure ulcer-related problems are central parts of the nursing profession and fall within their area of responsibilities. The nurses are in a unique position to identify patients with these problems, and this thesis can provide clinical perspectives that are important for daily practice and might assist in selecting preventive interventions.

The magnitude of the interface pressure on the pressure-redistribution mattresses currently being used in health-care settings are usually provided by the manufactures, and these values are supported in this thesis. These values might provide a false sense of security that the pressure levels are not harmful and that the use of these products will save the patient from tissue damage. However, this thesis showed that under clinically relevant conditions, a 
pressure that is considered to be not harmful can affect the microcirculation and potentially cause tissue damage. The clinical implication of this is that healthcare staff must be aware of this and must carefully evaluate the impact on the patient of the mattress being used by regularly skin assessments.

This thesis has revealed for the first time that PIV and RH are present at different depths under clinically relevant conditions, and it identified a population of individuals not identified in previous experimental studies that seems to have a vulnerability to pressure exposure due to a lack of these responses. Because these individuals are unable to respond to pressure exposure with these protective mechanisms, support surfaces might not be the primary preventive intervention for these individuals. Instead, pressure relief with an individualized turning regimen might be more appropriate. In this thesis, many of the persons with diabetes were identified with this vulnerability, and based on experimental studies one can speculate whether this group in general would benefit the most from turning regimens. Furthermore, it is important for the nurse to know that some individuals considered to be at lowrisk, including young and healthy individuals, also have this vulnerability and, therefore, skin and risk assessment is important in all groups of patients.

Finally, in every-day clinical practice nursing staff routinely evaluate pressure ulcer risk in their patients and struggle to implement their assessments into individualized, evidence-based, and cost-effective strategies for pressure ulcer prevention. Risk assessment scales can be used as an alert assessment, but in critically ill populations it is common that a majority of the patients fulfill the criteria of high-risk patients (Tescher et al., 2012). It is well known by clinicians that risk assessment scales do not cover all aspects of risk, and there is a need to develop other types of assessments such as direct biological measurements that have the potential to reveal physiological conditions that are relevant for pressure ulcer etiology (Sprigle et al., 2013). This thesis indicates that PIV and RH explored in a tissue volume with a combination of LDF and PPG might have the potential to be predictors of pressure ulcer development. With further development and validation of the system, it might become a valuable complement to the risk assessment tools currently in use. However, the risk assessments scales are important tools available in nursing practice today and should be used while waiting for new possibilities to assess pressure ulcer risk. 


\section{Future research}

This thesis has generated several new approaches for future research.

- Characterize PIV and RH in high-risk populations and explore the relationship between these responses and pressure ulcer risk assessment scales.

- Explore the potential of PIV and RH to be predictors for pressure ulcer development and the stability of the PIV response over time.

- Explore the link between endothelial dysfunction and pressure ulcer development as a part of the new pressure ulcer conceptual framework.

- Evaluate the relative contribution of tissue compression in loaded tissue to the increase in blood flow observed with PPG.

- Further analyze the collected LDF and PPG signals in terms of nonlinear analysis, for example, spectral analysis to explore myogenic activity of the smooth muscle cell, the neurogenic activity of the vessel wall, and other endothelial activities in relation to different depths and physiological conditions. 


\section{CONCLUSIONS}

Based on the results of the studies included herein, this thesis has

- Identified vascular mechanisms of importance for pressure ulcer development - i.e. PIV and RH - and revealed for the first time that PIV and $\mathrm{RH}$ are present at different depths under clinically relevant conditions. It has also found individuals not identified in previous experimental studies who seem to have a vulnerability to pressure exposure because they lack these responses.

- Added a new perspective to the traditional view of microcirculation as solely a transport function in pressure ulcer etiology by including blood flow regulation and endothelial functions that are anchored in clinically relevant studies.

- Shown that the same interface pressure magnitudes while lying on pressure-redistribution support surfaces can give different vascular responses in different individuals and that interface pressure magnitudes that are usually considered to be harmless can affect the microcirculation in different tissue structures.

- Shown large blood flow variations at different tissue depths during and after pressure exposure of the sacral tissue with no differences in mean blood flow responses between young and healthy individuals, old and healthy individuals, and old inpatients.

- Shown differences in individual blood flow responses in terms of PIV and $\mathrm{RH}$ with a larger proportion of individuals lacking these responses in the deeper tissue structures compared to more superficial tissue structures and on the V-E foam/air mattress compared to the alternating pressure mattress and the standard hospital mattress.

- Shown that the evaluation of pressure-redistribution support surfaces in terms of mean blood flow during and after tissue exposure is not feasible but that assessment of PIV and $\mathrm{RH}$ at different tissue depths could provide a new possibility for assessing individualized physiological measurements of mechanisms known to be related to pressure ulcer development.

- Found that blood flow measurements at $1 \mathrm{~mm}, 2 \mathrm{~mm}$, and $10 \mathrm{~mm}$ tissue depths in sacral tissue are relevant based on tissue thickness and the relative compression in loaded tissue. 



\section{SVENSK SAMMANFATTNING}

Trycksår relateras ofta till sjukdom och begränsad rörelseförmåga. Att leva med trycksår påverkar personens liv på många olika plan. Trycksår orsakar stora kostnader för sjukvården och samhället $\mathrm{i}$ stort men är oftast möjliga att förebygga. I klinisk verksamhet har stort focus legat på att identifiera patienter som är i risk för att utveckla trycksår och implementera preventiva åtgärder för dessa patienter. Strukturerade riskbedömningar och användning av speciella tryckfördelande madrasser, som är konstruerade för att förebygga trycksår, är vanligt förekommande i detta arbete. Ändå är det svårt att välja den mest kostnadseffektiva madrassen för kliniskt bruk, framför allt på grund av den bristfälliga utvärderingen av dessa produkter. Vidare, är etiologin om trycksår inte helt klarlagd, men kunskap om nyckelkomponenter och deras inverkan på vävnadsskada påverkar kliniska riktlinjer om riskbedömning och prevention av trycksår.

Det övergripande syftet med denna avhandling var att kombinera optiska mätmetoder i ett system som kan mäta blodflödesförändringar på olika djup, för att identifiera relevanta mikrocirkulatoriska mekanismer av betydelse för trycksårsetiologin, i kliniskt relevanta situationer och i relation till utvärderingen av trycksårsförebyggande madrasser.

Avhandlingen består av fyra kvantitativa experimentella delstudier som mätte blodflödesförändringar före, under och efter tryckexponering av vävnaden i sacrum. Två optiska metoder, laser Doppler Flowmetry (LDF) och fotopletysmografi (PPG) kombinerades i ett nytt system som kunde mäta blodflödesförändringar på olika vävnadsdjup. Studie I och II var deskriptiva och undersökte blodflödesförändringar på olika djup hos 17 friska försökspersoner över 60 år. I studie I så låg försökspersonerna på rygg på en hård brits med mätsystemet integrerat $\mathrm{i}$ britsen. Då uppmättes mycket höga tryck (minst $220 \mathrm{mmHg}$ ) och blodflödet relaterades till vävnadstjocklek och relativ kompression under denna belastning. I studie II belastades vävnaden i sacrum med $37,5 \mathrm{mmHg}$ och $50,0 \mathrm{mmHg}$ i magläge och blodflödesförändringarna utforskades. I Studie III och IV inkluderades 42 friska personer mellan 18-64 år, 38 friska personer över 65 år och 35 inneliggande patienter över 65 år. I Studie III gjordes jämförande analyser av blodflödesförändringar och tryck mellan de tre studiegrupperna och i studie IV mellan olika madrasser. Studierna undersökte microcirkulatoriska fenomen som tryckinducerad vasodilatering (PIV) och reaktiv hyperemi (RH). 
Resultatet i Studie I visade att vävnaden i sacrum har en medeltjocklek på $26 \pm$ $13 \mathrm{~mm}$ och under exponering av tryck på minst $220 \mathrm{mmHg}$ så är medeltjockleken $10 \pm 5 \mathrm{~mm}$. Detta ledde till att mätdjupen i Studie III och IV valdes till $1 \mathrm{~mm}, 2 \mathrm{~mm}$ och $10 \mathrm{~mm}$. Blodflödesvariationerna på olika djup under och efter tryckexponering av vävnaden i sacrum var stora och jämförelser av medelblodflöde visade inte på några skillnader mellan de olika studiegrupperna. Det vanligaste blodflödessvaret var PIV, fastän det var några personer som uppvisade en minskning av blodflödet, benämnt som avsaknad av PIV. 40,0-85,7 \% av personerna hade RH beroende på mätdjup (Studie III). $24-26 \%$ av personerna i de tre studiegrupperna i studie III hade avsaknad av både PIV och RH, benämnt som högrisk-blodflödessvar och detta skulle kunna vara uttryck för en extra sårbarhet för tryckexponering. I studie IV hade 7-8 \% i de friska grupperna och $14 \%$ av patienterna detta högrisk-blodflödessvar på tre eller fyra madrasser. Patienterna hade högre tryck i sacrum liggandes på madrasserna än de friska grupperna i studie III och IV men det var inga skillnader i blodflödessvaret mellan grupperna. Trycket som uppmättes i ryggläge var så pass lågt att det kan anses ofarligt utifrån klinisk praxis men resultaten visade att det ändå var tillräckligt för att påverka mikrocirkulationen i olika vävnadsstrukturer och kanske åstadkomma vävnadsskada om det kvarstod. Resultaten visade på skillnader mellan individuella blodflödessvar så som PIV och RH; en större andel individer saknade dessa mekanismer i djupare vävnadsstrukturer och i högre grad på en viscoelastisk skum/luftmadrass jämfört med de övriga madrasserna.

Denna avhandling identifierade mikrocirkulatoriska mekanismer av betydelse för utveckling av trycksår, dvs. PIV och RH och visade för första gången att dessa mekanismer förekommer på olika djup i vävnaden under kliniskt relevanta förhållanden. Det visades också för första gången att det finns personer som saknar både PIV och RH och därför kanske har en sårbarhet för tryckexponering. Avhandlingen har också lagt till ett nytt perspektiv på mikrocirkulationen i förhållande till trycksårsetiologin, i termer av reglering av blodflöde och endotelfunktion, som är förankrade i kliniskt relevanta studier. Slutligen visades att utvärdering av trycksårsförebyggande madrasser genom bedömning av medelblodflöde under och efter tryckexponering av vävnad inte är möjlig. Dock skulle bedömning av PIV och RH kunna vara en ny möjlighet att kunna genomföra objektiva individuella fysiologiska mätningar av mekanismer som är relaterade till utveckling av trycksår. 


\section{ACKNOWLEDGEMENTS}

I am grateful to all of you who have supported me and contributed to this thesis. Special thanks to:

All participants in the studies for giving of your time. Many life stories have been entrusted to me, thank you!

Margareta Lindgren, main supervisor, for generously sharing your knowledge and having the patience and encouragement to allow me to grow into an independent researcher.

Anna-Christina Ek, supervisor, for introducing me to the world of science and sharing your great expertise in research. You have been a major discussion partner for your stubborn $\mathrm{PhD}$ student.

Maria Engström, supervisor and former director of Agora Link, for being supportive in my role as a PhD student and for guidance in collaboration with the industry.

Lars-Göran Lindberg, supervisor, for giving me valuable technical assistance and knowledge and to his colleague at IMT, research engineer Bengt Ragnemalm, for providing excellent and timely technical assistance.

Ulrika Källman, co-author and research colleague, for fruitful discussions of most aspects of my research, but also for being a good listener and true friend. We have had many pleasant times and good laughs.

Anita Danielsson, who provided assistance with the clinical study and who had the enthusiasm, courage and persistence to become a competent member of the team and for being a very good friend. Thank you Kerstin Gustavsson for assistance during the last year. With many years of experience of clinical studies and your open mind, you quickly became a valuable help. 
Claes Post, for guiding me patiently during this period in my life with knowledge, experience, and wisdom. You have generously shared your extensive personal network with me and have played an important role in my becoming an independent researcher by knowing what I want and how to stand up for it. Your questions have always pushed me forward.

Folke Sjöberg, co-author, for sharing your great knowledge in microcirculation. Our meetings are short and concise, but I always leave with enthusiasm and confidence and many new thoughts.

Toste Länne, co-author, for allowing me to use your research resources and giving me valuable support in writing, and to Christina Svensson and Elisabet Kindberg, biomedical scientists in his department, for carrying out the ultrasound measurements under the bench.

Malin Hammar, care unit manager at the Department of Hand Surgery, Plastic Surgery and Burns, for supporting me with flexible working hours and positive words. You a have made me felt that I am still a part of the department despite periods of absence. To all my colleagues at the department, for your interest, help with recruiting patients, and friendly support, especially Åsa Johansson, Eva Lago, and Johan Thorfinn.

Elsebet Westin, former clinical specialist at ArjoHuntleigh, for your generosity and believing and showing interest in the research project.

All Senior Lecturers, doctoral students, and others at the Department of Medical and Health Science, Division of Nursing Science, for discussions, friendship, and help. Special thanks to Lena N, Carina H, Jenny D, and Carina $\mathbf{W}$ for many laughs but also for being truly supportive in times of need.

Ingegerd Ahldén, my kindred spirit, for giving me strength, faith, and recovery during this period. You have walked by my side and given me a different perspective on life. My life has never been the same since you became a part of it, I am so grateful for that.

Linda Rattfält, former $\mathrm{PhD}$ colleague and special friend, for being a great inspiration. You have walked the path in front of me and shown me the way. With in-depth discussions of science, eased by talks of crafts and pottery, you have been a large part of my being able to finish my tasks. 
All former colleagues at the Department of Acute Internal Medicine, for your interest, friendship, and help with recruiting patients, especially Irene. Thank you Linda $\mathbf{L}$ for becoming such a good friend.

The staff at the Departments of Neurology and Geriatric Medicine for being so helpful in recruiting study patients and accepting my visits to the wards on days, evenings, and weekends. Thank you for your patience.

Tomas Strömberg and his research group ThABO at IMT, especially Marcus, Ingemar, and Hanna, for welcoming me into your group. In friendly discussions, I have learned so much about biomedical optics.

Stefan Klintsröm, Director of Forum Scientium, for your support, always believing in my skills, and giving me a context as a $\mathrm{PhD}$ student in the life sciences.

LARC, especially to Nora, Mats, Lotta L-Å, Lina, Karin, and Lotta J, for offering a working place in a moment of homelessness, providing excellent statistical and scientific methodological expertise, and good coffee. I have always felt very welcome, but you have let me be in my bubble for as long as I liked.

Gunilla Sydsjö, who helped me reconquer my life and by that made this thesis possible.

Last, but closest to my heart, my family! To Patrik, not knowing what this journey meant but always being truly supportive! Vidar and Henning for reminding me what is most important in the world, and my beloved twin sister Johanna for letting me have a good cry against your shoulder and for sharing my joy in times of success.

The research in this thesis was funded by the Swedish Research Council, the Faculty of Health Sciences and Materials in Medicine at Linköping University, the Strategic Research Area at the County Council of Östergötland and Linköping University, the Centre of Senses, the County Council of Östergötland, King Gustaf V and Queen Victoria's Freemason Foundation, NovaMedTech, and the European Union Regional Development Fund. 



\section{REFERENCES}

Abraham, P., Fromy, B., Merzeau, S., Jardel, A., Saumet, J.L., 2001. Dynamics of local pressure-induced cutaneous vasodilation in the human hand. Microvasc Res 61 (1), 122-129.

Allen, J., 2007. Photoplethysmography and its application in clinical physiological measurement. Physiol Meas 28 (3), R1-39.

Baath, C., Idvall, E., Gunningberg, L., Hommel, A., 2014. Pressure-reducing interventions among persons with pressure ulcers: results from the first three national pressure ulcer prevalence surveys in Sweden. J Eval Clin Pract 20 (1), 58-65.

Bedo, J., 2013. Reducing hospital-acquired pressure damage: an NHS acute trust initiative. Br J Nurs 22 (20), S24-28.

Bennett, G., Dealy, C., Posnett, J., 2004. The cost of pressure ulcer in the UK. Age and Ageing 33 (3), 230-235.

Bennett, L., Kavner, D., Lee, B.Y., Trainor, F.S., Lewis, J.M., 1981. Skin Blood Flow in Seated Geriatric Patients. Arch Phys Med Rehabil 62, 392-398.

Berlowitz, D.R., Brienza, D.M., 2007. Are all pressure ulcers the result of deep tissue injury? A review of the literature. Ostomy Wound Manage 53 (10), 34-38.

Bertuglia, S., Colantuoni, A., Arnold, M., Witte, H., 1996. Dynamic coherence analysis of vasomotion and flow motion in skeletal muscle microcirculation. Microvasc Res 52 (3), 235-244.

Binggeli, C., Spieker, L.E., Corti, R., Sudano, I., Stojanovic, V., Hayoz, D., Luscher, T.F., Noll, G., 2003. Statins enhance postischemic hyperemia in the skin circulation of hypercholesterolemic patients: a monitoring test of endothelial dysfunction for clinical practice? J Am Coll Cardiol 42 (1), 7177.

Binzoni, T., Tchernin, D., Hyacinthe, J.N., Van De Ville, D., Richiardi, J., 2013. Pulsatile blood flow in human bone assessed by laser-Doppler flowmetry and the interpretation of photoplethysmographic signals. Physiol Meas 34 (3), N25-40.

Black, J., Baharestani, M., Cuddigan, J., Dorner, B., Edsberg, L., Langemo, D., Posthauer, M.E., Ratliff, C., Taler, G., 2007. National Pressure Ulcer Advisory Panel's updated pressure ulcer staging system. Dermatol Nurs 19 (4), 343-349; quiz 350. 
Bouten, C., Oomens, C.W.J., Baaijens, F., Bader, D., L., 2003. The etiology of pressure ulcers: Skin deep or muscle bound? Arch Phys Med Rehabil 84 (april), 616-619.

Braverman, I.M., 2000. The cutaneous microcirculation. J Investig Dermatol Symp Proc 5 (1), 3-9.

Braverman, I.M., 1997. The cutaneous microcirculation: ultrastructure and microanatomical organization. Microcirculation 4 (3), 329-340.

Bridel, J., 1993. The aetiology of pressure sores. Journal of Wound Care 2 (4), 230-238.

Ceelen, K.K., Stekelenburg, A., Loerakker, S., Strijkers, G.J., Bader, D.L., Nicolay, K., Baaijens, F.P., Oomens, C.W., 2008. Compression-induced damage and internal tissue strains are related. J Biomech 41 (16), 33993404.

Chan, B.C., Nanwa, N., Mittmann, N., Bryant, D., Coyte, P.C., Houghton, P.E., 2013. The average cost of pressure ulcer management in a community dwelling spinal cord injury population. Int Wound J 10 (4), 431-440.

Clancy, M.J., 2013. Pressure redistribution devices: what works, at what cost and what's next? J Tissue Viability 22 (3), 57-62.

Coleman, S., Gorecki, C., Nelson, E.A., Closs, S.J., Defloor, T., Halfens, R., Farrin, A., Brown, J., Schoonhoven, L., Nixon, J., 2013. Patient risk factors for pressure ulcer development: systematic review. Int J Nurs Stud 50 (7), 974-1003.

Coleman, S., Nixon, J., Keen, J., Wilson, L., McGinnis, E., Dealey, C., Stubbs, N., Farrin, A., Dowding, D., Schols, J.M., Cuddigan, J., Berlowitz, D., Jude, E., Vowden, P., Schoonhoven, L., Bader, D.L., Gefen, A., Oomens, C.W., Nelson, E.A., 2014. A new pressure ulcer conceptual framework. J Adv Nurs, [Epub ahead of print].

Cracowski, J.L., Minson, C.T., Salvat-Melis, M., Halliwill, J.R., 2006. Methodological issues in the assessment of skin microvascular endothelial function in humans. Trends Pharmacol Sci 27 (9), 503-508.

Cutolo, M., Pizzorni, C., Secchi, M.E., Sulli, A., 2008. Capillaroscopy. Best Pract Res Clin Rheumatol 22 (6), 1093-1108.

Daniel, R.K., Priest, D.L., Wheatley, D.C., 1981. Etiologic Factors in Pressure Sores: An Experimental Model. Arch Phys Med Rehabil 62, 492-498.

Dinsdale, S.M., 1974. Decubitus ulcers: role of pressure and friction in causation. Arch Phys Med Rehabil 55 (4), 147-152.

Ek, A.-C., Gustavsson, G., Lewis, D.H., 1987. Skin blood flow in relation to external pressure and temperature in the supine position on a standard mattress. Scandinavian Journal of Rehab Medicine 19, 121-126. 
Ek, A.-C., Lewis, D.H., Zetterqvist, H., Svensson, P.-G., 1984. Skin blood flow in an area at risk for pressure sore. Scandinavian Journal of Rehab Medicine $16,85-89$.

Fredriksson, I., Larsson, M., Stromberg, T., 2009. Measurement depth and volume in laser Doppler flowmetry. Microvasc Res 78 (1), 4-13.

Fromy, B., Abraham, P., Saumet, J.L., 1998. Non-nociceptive capsaicin-sensitive nerve terminal stimulation allows for an original vasodilatory reflex in the human skin. Brain Res 811 (1-2), 166-168.

Fromy, B., Lingueglia, E., Sigaudo-Roussel, D., Saumet, J.L., Lazdunski, M., 2012. Asic3 is a neuronal mechanosensor for pressure-induced vasodilation that protects against pressure ulcers. Nat Med 18 (8), 12051207.

Fromy, B., Merzeau, S., Abraham, P., Saumet, J.L., 2000. Mechanisms of the cutaneous vasodilator response to local external pressure application in rats: involvement of CGRP, neurokinins, prostaglandins and NO. Br J Pharmacol 131 (6), 1161-1171.

Fromy, B., Sigaudo-Roussel, D., Gaubert-Dahan, M.L., Rousseau, P., Abraham, P., Benzoni, D., Berrut, G., Saumet, J.L., 2010. Aging-associated sensory neuropathy alters pressure-induced vasodilation in humans. J Invest Dermatol 130 (3), 849-855.

Garry, A., Sigaudo-Roussel, D., Merzeau, S., Dumont, O., Saumet, J.L., Fromy, B., 2005. Cellular mechanisms underlying cutaneous pressure-induced vasodilation: in vivo involvement of potassium channels. Am J Physiol Heart Circ Physiol 289 (1), H174-180.

Gaubert, M.L., Sigaudo-Roussel, D., Tartas, M., Berrut, G., Saumet, J.L., Fromy, B., 2007. Endothelium-derived hyperpolarizing factor as an in vivo backup mechanism in the cutaneous microcirculation in old mice. J Physiol 585 (Pt 2), 617-626.

Gefen, A., 2007. Risk factors for a pressure-related deep tissue injury: a theoretical model. Med Biol Eng Comput 45 (6), 563-573.

Gefen, A., Levine, J., 2007. The false premise in measuring body-support interface pressures for preventing serious pressure ulcers. J Med Eng Technol 31 (5), 375-380.

Gil-Agudo, A., De la Pena-Gonzalez, A., Del Ama-Espinosa, A., Perez-Rizo, E., Diaz-Dominguez, E., Sanchez-Ramos, A., 2009. Comparative study of pressure distribution at the user-cushion interface with different cushions in a population with spinal cord injury. Clin Biomech (Bristol, Avon) 24 (7), 558-563. 
Giles, T.D., Sander, G.E., Nossaman, B.D., Kadowitz, P.J., 2012. Impaired vasodilation in the pathogenesis of hypertension: focus on nitric oxide, endothelial-derived hyperpolarizing factors, and prostaglandins. J Clin Hypertens (Greenwich) 14 (4), 198-205.

Goossens, R.H.M., Rithalia, S.V.S., 2008. Physiological response of the heel tissue on pressure relief between three alternating pressure air mattresses. Journal of Tissue Viability 17 (1), 10-14.

Gorecki, C., Lamping, D.L., Brown, J.M., Madill, A., Firth, J., Nixon, J., 2010. Development of a conceptual framework of health-related quality of life in pressure ulcers: a patient-focused approach. Int J Nurs Stud 47 (12), 1525-1534.

Gunningberg, L., Donaldson, N., Aydin, C., Idvall, E., 2012. Exploring variation in pressure ulcer prevalence in Sweden and the USA: benchmarking in action. J Eval Clin Pract 18 (4), 904-910.

Gunningberg, L., Hommel, A., Baath, C., Idvall, E., 2013. The first national pressure ulcer prevalence survey in county council and municipality settings in Sweden. J Eval Clin Pract 19 (5), 862-867.

Hagblad, J., Lindberg, L.G., Kaisdotter Andersson, A., Bergstrand, S., Lindgren, M., Ek, A.C., Folke, M., Linden, M., 2010. A technique based on laser Doppler flowmetry and photoplethysmography for simultaneously monitoring blood flow at different tissue depths. Med Biol Eng Comput 48 (5), 415-422.

Herrman, E.C., Knapp, C.F., Donofrio, J.C., Salcido, R., 1999. Skin perfusion responses to surface pressure-induced ischemia: implication for the developing pressure ulcer. J Rehabil Res Dev 36 (2), 109-120.

Humeau, A., Steenbergen, W., Nilsson, H., Stromberg, T., 2007. Laser Doppler perfusion monitoring and imaging: novel approaches. Med Biol Eng Comput 45 (5), 421-435.

Jakobsson, A., Nilsson, G.E., 1993. Prediction of sampling depth and photon pathlength in laser Doppler flowmetry. Med Biol Eng Comput 31 (3), 301307.

Jan, Y.K., Lee, B., Liao, F., Foreman, R.D., 2012. Local cooling reduces skin ischemia under surface pressure in rats: an assessment by wavelet analysis of laser Doppler blood flow oscillations. Physiol Meas 33 (10), 1733-1745.

Jiang, L.P., Tu, Q., Wang, Y., Zhang, E., 2011. Ischemia-reperfusion injuryinduced histological changes affecting early stage pressure ulcer development in a rat model. Ostomy Wound Manage 57 (2), 55-60. 
Jonsson, A., Lindén, M., Lindgren, M., Malmqvist, L.-Å., Bäcklund, Y., 2005. Evaluation of antidecubitus mattresses. Medical \& Biological Engineering \& Computing 43, 541-547.

Judy, D., Brooks, B., Fennie, K., Lyder, C., Burton, C., 2011. Improving the detection of pressure ulcers using the TMI ImageMed system. Adv Skin Wound Care 24 (1), 18-24.

Kallman, U., Lindgren, M., 2014. Predictive validity of 4 risk assessment scales for prediction of pressure ulcer development in a hospital setting. Adv Skin Wound Care 27 (2), 70-76.

Kasuya, A., Sakabe, J., Tokura, Y., 2014. Potential application of in vivo imaging of impaired lymphatic duct to evaluate the severity of pressure ulcer in mouse model. Sci Rep 4, 4173.

Koitka, A., Abraham, P., Bouhanick, B., Sigaudo-Roussel, D., Demiot, C., Saumet, J.L., 2004. Impaired pressure-induced vasodilation at the foot in young adults with type 1 diabetes. Diabetes 53 (3), 721-725.

Kosiak, M., 1959. Etiology and Pathology of Ischemic Ulcers. Arch Phys Med Rehabil, 62-68.

Kosiak, M., 1961. Etiology of Decubitus Ulcers. Arch Phys Med Rehabil 42, 1929.

Kottner, J., Dassen, T., Lahmann, N., 2010. Prevalence of deep tissue injuries in hospitals and nursing homes: two cross-sectional studies. Int J Nurs Stud 47 (6), 665-670.

Larkin, S.W., Williams, T.J., 1993. Evidence for sensory nerve involvement in cutaneous reactive hyperemia in humans. Circ Res 73 (1), 147-154.

Liao, F., Burns, S., Jan, Y.K., 2013. Skin blood flow dynamics and its role in pressure ulcers. J Tissue Viability 22 (2), 25-36.

Lindberg, L.G., Oberg, P.A., 1991. Photoplethysmography. Part 2. Influence of light source wavelength. Med Biol Eng Comput 29 (1), 48-54.

Lindberg, L.G., Tamura, T., Oberg, P.A., 1991. Photoplethysmography. Part 1. Comparison with laser Doppler flowmetry. Med Biol Eng Comput 29 (1), 40-47.

Lindberg, L.G., Öberg, P.Å., 1993. Optical properties of blood in motion. Optical Engineering 32 (2), 253-257.

Linder-Ganz, E., Engelberg, S., Scheinowitz, M., Gefen, A., 2006. Pressure-time cell death threshold for albino rat skeletal muscles as related to pressure sore biomechanics. J Biomech 39 (14), 2725-2732.

Linder-Ganz, E., Gefen, A., 2004. Mechanical compression-induced pressure sores in rat hindlimb: muscle stiffness, histology, and computational models. J Appl Physiol 96 (6), 2034-2049. 
Linder-Ganz, E., Shabshin, N., Itzchak, Y., Gefen, A., 2007. Assessment of mechanical conditions in sub-dermal tissues during sitting: a combined experimental-MRI and finite element approach. J Biomech 40 (7), 14431454.

Lindgren, M., Unosson, M., Krantz, A.-M., Ek, A.-C., 2002. A risk assessment scale for the prediction of pressure sore development: reliability and validity. Journal of Advanced Nursing 38 (2), 190-199.

Lupi, O., Semenovitch, I., Treu, C., Bouskela, E., 2008. Orthogonal polarization technique in the assessment of human skin microcirculation. Int $\mathrm{J}$ Dermatol 47 (5), 425-431.

Manorama, A., Meyer, R., Wiseman, R., Bush, T.R., 2013. Quantifying the effects of external shear loads on arterial and venous blood flow: implications for pressure ulcer development. Clin Biomech (Bristol, Avon) 28 (5), 574578.

Mayrovitz, H.N., Smith, J., 1998. Heel-skin microvascular blood perfusion responses to sustained pressure loading and unloading. Microcirculation $5(2-3), 227-233$.

McInnes, E., Jammali-Blasi, A., Bell-Syer, S., Dumville, J., Cullum, N., 2012. Preventing pressure ulcers--Are pressure-redistributing support surfaces effective? A Cochrane systematic review and meta-analysis. Int J Nurs Stud 49 (3), 345-359.

Miller, G.E., Seale, J., 1981. Lymphatic clearance during compressive loading. Lymphology 14 (4), 161-166.

Miller, S., Parker, M., Blasiole, N., Beinlich, N., Fulton, J., 2013. A prospective, in vivo evaluation of two pressure-redistribution surfaces in healthy volunteers using pressure mapping as a quality control instrument. Ostomy Wound Manage 59 (2), 44-48.

Moysidis, T., Niebel, W., Bartsch, K., Maier, I., Lehmann, N., Nonnemacher, M., Kroeger, K., 2011. Prevention of pressure ulcer: interaction of body characteristics and different mattresses. Int Wound J 8 (6), 578-584.

Naslund, J., Pettersson, J., Lundeberg, T., Linnarsson, D., Lindberg, L.G., 2006. Non-invasive continuous estimation of blood flow changes in human patellar bone. Med Biol Eng Comput 44 (6), 501-509.

Nilsson, G.E., Salerud, E.G., Strömberg, N.O.T., Wårdell, K., 2003. Laser Doppler perfusion Monitoring and Imaging. In: Vo-Dinh, I.T. (Ed.), Biomedical photonics handbook. CRC Press, Boca Raton, Florida, pp. 124. 
Nilsson, G.E., Tenland, T., Öberg, P.Å., 1980. Evaluation of a Laser Doppler Flowmeter for Measurement of Tissue Blood Flow. IEEE Transactions on Biomedical Engineering BME-27 (10), 597-604.

Nilsson, G.E., Tenland, T., Öberg, P.Å., 1980. A new instrument for continous measurement of tissue blood flow by light beating spectroscopy. IEEE Transactions on Biomedical Engineering 21 (1), 12-19a.

Noble, M., Voegeli, D., Clough, G.F., 2003. A comparison of cutaneous vascular responses to transient pressure loading in smokers and nonsmokers. J Rehabil Res Dev 40 (3), 283-288.

NPUAP/EPUAP, 2009. Prevention and Treatment of Pressure ulcers: Clinical Practice Guideline. National Pressure Ulcer Advisory Panel, Washington, DC.

NPUAP/S3I, 2007. Support Surface Standards Initiative, Terms and definitions related to support surfaces Ver. 01/29/2007 . http://www.npuap.org/wpcontent/uploads/2012/03/NPUAP_S3I_TD.pdf Avaliable 2014-07-10.

Oomens, C.W., Loerakker, S., Bader, D.L., 2010. The importance of internal strain as opposed to interface pressure in the prevention of pressure related deep tissue injury. J Tissue Viability 19 (2), 35-42.

Oomens, C.W.J., Bressers, O.F.J.T., Bosboom, E.M.H., Bouten, C., Bader, D., L., 2003. Can loaded interface characteristics influence strain distributions in muscle adjacent to bony prominences? Computer Methods in Biomechanical Engineering 6 (3), 171-180.

Peirce, S.M., Skalak, T.C., Rodeheaver, G.T., 2000. Ischemia-reperfusion injury in chronic pressure ulcer formation: a skin model in the rat. Wound Repair Regen 8 (1), 68-76.

Polit, D.F., Beck, C.T., 2007. Nursing Research: Generating and Assessing Evidence for Nursing Practice Lippincott Williams \& Wilkins, New York.

Reddy, N.P., Cochran, G.V., 1981. Interstitial fluid flow as a factor in decubitus ulcer formation. J Biomech 14 (12), 879-881.

Reenalda, J., Jannink, M., Nederhand, M., M, I.J., 2009. Clinical use of interface pressure to predict pressure ulcer development: a systematic review. Assist Technol 21 (2), 76-85.

Rithalia, S., 2005. Assessment of patient support surfaces: principle, practice and limitations. J Med Eng Technol 29 (4), 163-169.

Roustit, M., Cracowski, J.L., 2013. Assessment of endothelial and neurovascular function in human skin microcirculation. Trends Pharmacol Sci 34 (7), 373-384. 
Roustit, M., Cracowski, J.L., 2012. Non-invasive assessment of skin microvascular function in humans: an insight into methods. Microcirculation 19 (1), 47-64.

Sae-Sia, W., Wipke-Tevis, D.D., Williams, D.A., 2007. The effect of clinically relevant pressure duration on sacral skin blood flow and temperature in patients after acute spinal cord injury. Arch Phys Med Rehabil 88 (12), 1673-1680.

Salcido, R., Donfiro, J.C., Fisher, S.B., LeGrand, E.K., Dickey, K., Carney, J.M., Schosser, R., Liang, R., 1994. Histopathogy of Pressure Ulcers as a Result of Sequential Computer-Controlled Pressure Sessions in a Fuzzy Rat Model. Advances in Wound Care 7 (5), 23-40.

Sanada, H., Nagakawa, T., Yamamoto, M., Higashidani, K., Tsuru, H., Sugana, J., 1997. The Role of Skin Blood Flow in Pressure Ulcer Development During Surgery. Advances in Wound Care 10 (6), 29-34.

Sandberg, M., Zhang, Q., Styf, J., Gerdle, B., Lindberg, L.-G., 2005. Non-invasive monitoring of muscle blood perfusion by photopletysmography: evaluation of a new application. Acta Physiol Scand 183, 335-343.

Sandberg, M., Zhang, Q., Styf, J., Gerdle, B., Lindberg, L.G., 2005. Non-invasive monitoring of muscle blood perfusion by photoplethysmography: evaluation of a new application. Acta Physiol Scand 183 (4), 335-343.

Sandby-Moller, J., Poulsen, T., Wulf, H.C., 2003. Epidermal thickness at different body sites: relationship to age, gender, pigmentation, blood content, skin type and smoking habits. Acta Derm Venereol 83 (6), 410413.

Schubert, V., Fagrell, B., 1991. Evaluation of the dynamic cutaneous postischaemic hyperaemia and thermal response in elderly subjects and in an area at risk for pressure sores. Clin Physiol 11 (2), 169-182.

Schubert, V., Fagrell, B., 1989. Local skin pressure and its effects on skin microcirculation as evaluated by laser-Doppler fluxmetry. Clin Physiol 9 (6), 535-545.

Schubert, V., Héraud, J., 1994. The effects of Pressure and Shear on Skin Microcirculation in Elderly Stroke Patients Lying in Supine or Semirecumbent Positions. Age and Ageing 23, 405-410.

Severens, J.L., Habraken, J.M., Duivenvoorden, S., Frederiks, C.M., 2002. The cost of illness of pressure ulcers in The Netherlands. Adv Skin Wound Care 15 (2), 72-77.

Shilo, M., Gefen, A., 2012. Identification of capillary blood pressure levels at which capillary collapse is likely in a tissue subjected to large compressive 
and shear deformations. Comput Methods Biomech Biomed Engin 15 (1), 59-71.

Shoham, N., Gefen, A., 2012. Deformations, mechanical strains and stresses across the different hierarchical scales in weight-bearing soft tissues. J Tissue Viability 21 (2), 39-46.

Sonenblum, S.E., Vonk, T.E., Janssen, T.W., Sprigle, S.H., 2014. Effects of Wheelchair Cushions and Pressure Relief Maneuvers on Ischial Interface Pressure and Blood Flow in People With Spinal Cord Injury. Arch Phys Med Rehabil 95 (7), 1350-1357.

Sprigle, S., Sonenblum, S., Conner-Kerr, T., 2013. mobilityRERC state of the science conference: Individualizing pressure ulcer risk and prevention strategies. Disabil Rehabil Assist Technol 8 (6), 454-461.

Stekelenburg, A., Gawlitta, D., Bader, D.L., Oomens, C.W., 2008. Deep tissue injury: how deep is our understanding? Arch Phys Med Rehabil 89 (7), 1410-1413.

Stekelenburg, A., Strijkers, G.J., Parusel, H., Bader, D.L., Nicolay, K., Oomens, C.W., 2007. Role of ischemia and deformation in the onset of compression-induced deep tissue injury: MRI-based studies in a rat model. J Appl Physiol 102 (5), 2002-2011.

Stojadinovic, O., Minkiewicz, J., Sawaya, A., Bourne, J.W., Torzilli, P., de Rivero Vaccari, J.P., Dietrich, W.D., Keane, R.W., Tomic-Canic, M., 2013. Deep tissue injury in development of pressure ulcers: a decrease of inflammasome activation and changes in human skin morphology in response to aging and mechanical load. PLoS One 8 (8), e69223.

Sullivan, N., Schoelles, K.M., 2013. Preventing in-facility pressure ulcers as a patient safety strategy: a systematic review. Ann Intern Med 158 (5 Pt 2), 410-416.

Tescher, A.N., Branda, M.E., Byrne, T.J., Naessens, J.M., 2012. All at-risk patients are not created equal: analysis of Braden pressure ulcer risk scores to identify specific risks. J Wound Ostomy Continence Nurs 39 (3), 282-291.

Thein, H.H., Gomes, T., Krahn, M.D., Wodchis, W.P., 2010. Health status utilities and the impact of pressure ulcers in long-term care residents in Ontario. Qual Life Res 19 (1), 81-89.

Tortora, G.J., Derrickson, B., 2011. Principles of Anatomy and Physiology. John Wiley \& Sons, Inc, New York.

Treu, C.M., Lupi, O., Bottino, D.A., Bouskela, E., 2011. Sidestream dark field imaging: the evolution of real-time visualization of cutaneous microcirculation and its potential application in dermatology. Arch Dermatol Res 303 (2), 69-78. 
Tuma, R.F., Durán, W.N., Ley, K., 2008. Microcirculation. Elsevier/Academic Press, Amsterdam ; Boston.

TVS, 2010. Tissue Viability Society, Laboratory measurement of the interface pressures applied by active therapy support surfaces: a consensus document. J Tissue Viability 19 (1), 2-6.

Vanderwee, K., Clark, M., Dealy, C., Gunningberg, L., Defloor, T., 2007. Pressure ulcer prevalence in Europe: a pilot study. Journal of Evaluation in Clinical Practice 13, 227-235.

Wardell, K., Jakobsson, A., Nilsson, G.E., 1993. Laser Doppler perfusion imaging by dynamic light scattering. IEEE Trans Biomed Eng 40 (4), 309316.

WHO, 2004. Appropriate body-mass index for Asian populations and its implications for policy and intervention strategies. Lancet 363 (9403), 157163.

Witkowski, J.A., Parish, L.C., 1982. Histopathology of the decubitus ulcer. J Am Acad Dermatol 6, 1014-1021.

WMA, 2013. World Medical Association Declaration of Helsinki: ethical principles for medical research involving human subjects. JAMA 310 (20), 2191-2194.

Wong, B.J., Wilkins, B.W., Holowatz, L.A., Minson, C.T., 2003. Nitric oxide synthase inhibition does not alter the reactive hyperemic response in the cutaneous circulation. J Appl Physiol 95 (2), 504-510.

Wright, C.I., Kroner, C.I., Draijer, R., 2006. Non-invasive methods and stimuli for evaluating the skin's microcirculation. J Pharmacol Toxicol Methods $54(1), 1-25$.

Xakellis, G.C., Frantz, R.A., Arteaga, M., Meletiou, S., 1993. Dermal blood flow response to constant pressure in healthy older and younger subjects. J Gerontol 48 (1), M6-9.

Xiao, D.Z., Wu, S.Y., Mak, A.F., 2014. Accumulation of loading damage and unloading reperfusion injury--modeling of the propagation of deep tissue ulcers. J Biomech 47 (7), 1658-1664.

Zhang, Q., Lindberg, L.-G., Kadefors, R., Styf, J., 2001. A non-invasive measure of changes in blood flow in the human anterior tibial muscle. Eur J Appl Physiol 84, 448-452. 


\section{Papers}

The articles associated with this thesis have been removed for copyright reasons. For more details about these see:

http://urn.kb.se/resolve?urn=urn:nbn:se:liu:diva-109960 